\title{
DOCUMENTA \\ A CORRIDA DE TORAS DOS TIMBIRA
}

Curt Nimuendajú

Os Timbira são um povo física, lingüística e culturalmente caracterizado como da família Jê, que disperso, habitava o interior do Maranhão e partes limítrofes dos Estados do Pará, G oiás e Piauí. Esse povo existe ainda parcialmente, compondo-se hoje das seguintes tribos:

Timbira orientais:

Timbira de Araparytiua

Kukóekamekra e Krẽyé de Bacabal

Krẽyé de Cajuapára

Kre/púmkateye

Pukópye e Kríkateye

Gaviões

Apányekra (Canellas de Porquinhos)

Ramkókamekra (Canellas do Ponto)

Krahó

Timbira ocidentais:

Apinayé

Seus parentes mais próximos são os Kayapó do norte, os Suyá e os hoje extintos Kayapó do sul*.

Nenhuma das inúmeras cerimônias que constituem a vida pública entre os Timbira chama tanto a atenção dos civilizados quanto a corrida

\footnotetext{
* $\quad$ N.T. - Há fortes evidências de que os Panara (também conhecidos como Krenakarore), contatados no início da década de 70, sejam um grupo remanescente dos outrora numerosos Kayapó do sul. A conexão foi estabelecida pelos antropólogos Richard Heelas e Stephan Schwartzman, que desenvolveram pesquisa entre eles, respectivamente, nos anos 70 e 80.
} 
de toras. Isto se deve ao fato de que, depois da dança no pátio* da aldeia, essa é a cerimônia mais repetida na vida cotidiana desses índios e, dramaticamente, a mais impressionante. De outro lado, dificulta sua compreensão a vertiginosa velocidade do acontecimento que, em geral, está terminado antes que o visitante tenha tempo de vê-lo direito. Por essa razão, a maior parte das informações a seu respeito são, ao que parece, total ou parcialmente de segunda mão.

Ao se indagar a qualquer colono, na zona timbira e muito além dela, a respeito da corrida de toras, recebe-se logo como resposta que se trata de uma prova de casamento. Snethlage, que visitou, entre 1924 e 1926, várias tribos timbira, adere sem reserva a essa interpretação: o jovem timbira que pretende casar-se, diz ele, deverá carregar em passo acelerado uma pesada tora, percorrendo uma determinada distância. Caso não consiga isto, não estará apto para o casamento (Snethlage 1930:171, 183).

Infelizmente, essa interpretação, por mais simples e compreensível que pareça, é improcedente, como já se me tornara evidente por ocasião de minha primeira permanência entre os Ramkókamekra. Antes de mim, o pesquisador brasileiro Fróes Abreu (1931:187), que em 1928 passara alguns dias na mesma tribo, tinha chegado a essa mesma conclusão, escrevendo de maneira clara: "Antes de visitar os Canellas (=Ramkókamekra) ouvi dizer que os moços só se podiam casar quando tinham força de carregar tóros. Na aldeia indaguei da veracidade dessa affirmação e verifiquei que tal não se dava; o habito de carregar tóros é antes uma práctica de educação physica” . Da mesma maneira Oliveira, ao interrogar em 1926 o cacique apinayé José Dias Matúk, nada chegou a ouvir sobre uma prova de casamento, qualificando a corrida de toras dessa tribo como uma "demonstração de resistência" . Contrapõem-se a isso as informações, aliás absolutamente equivocadas, que Pompeu Sobrinho recebeu em 1929 e 1930, em Fortaleza, sobre o casamento dos Ramkókamekra: "Os que conseguiam levar o fardo (a tora de corrida) ao lugar determinado estavam aptos para contrahir matrimonio naquelle anno" .

É digno de menção que, nas cerimônias dos índios, o civilizado esteja, por todo lado, farejando provas de casamento; até mesmo a cura de formigas dos Maué e as curas de formigas e de marimbondos das tribos Guayana teriam sido interpretadas nesse sentido. Evidentemente, o civilizado, em virtude de sua própria maneira de sentir, tende a atribuir ao

* N.T. - Mittelplatz, literalmente, " praça do meio" . Optamos por utilizar " pátio", que é como Nimuendajú traduziu o termo na versão que fez para o português, em 1944, do original alemão de seu livro The Eastern Timbira, publicado em inglês por Lowie em 1946. 
casamento dos índios uma importância muito maior do que a que lhe conferem os próprios.

Aliás, já deviam ter chamado a atenção, até dos observadores mais superficiais, vários aspectos da corrida de toras que são inconciliáveis com uma prova de casamento. Entre estes estão, por exemplo, o fato de que o treino é sempre feito com duas toras, que os carregadores mudam constantemente, que entre os participantes estão tanto adolescentes quanto homens que já são avôs, que muitas vezes três corridas são realizadas no mesmo dia etc. Todas essas são circunstâncias das quais o singelo deduz tratar-se de uma competição esportiva entre duas equipes, da mesma ordem que o hóquei ou o jogo de bola de outras tribos americanas.

Os Timbira, por sua vez, há muito estão familiarizados com o equivocado modo de ver dos civilizados. Sendo assim, nesse particular, o corroboram à vontade, pois um Timbira costuma dizer aquilo que supõe agradar ao interlocutor. Da mesma maneira, aliás, que os Guarani, os quais de bom grado confirmavam a todos - como se pode ler nos livros escolares brasileiros - que o Bom Deus na língua deles se chamava "Tupan”, apesar de esse nome em sua mitologia ser atribuído a um demônio (do trovão) bem inferior, sendo seu deus supremo chamado por nome diferente.

Quero agora, segundo as minhas próprias observações entre os Ramkókamekra e outras tribos, tentar dar uma idéia da corrida de toras, procurando verificar, antes de tudo, quem são os participantes, em que ocasiões se realizam as corridas e como elas se desenvolvem. A corrida de toras, no entanto, depende de tal maneira da organização sociocerimonial dessas tribos, que é preciso adiantar alguns comentários sobre a mesma, tanto mais que as informações a respeito, fornecidas por Snethlage, são em vários pontos absolutamente falsas. Todavia, limitar-me-ei apenas às organizações indispensáveis para a compreensão da corrida de toras.

a) Os Ramkókamekra (que junto com os Apányekra, vêm sendo referidos pelos brasileiros como "Canellas", e cujos costumes servem como base principal desta descrição) habitam, com um efetivo de 298 cabeças, a aldeia Ponto, que se encontra no cerrado do sertão do Maranhão, a $78 \mathrm{~km}$ ao sul da cidadezinha de Barra do Corda. A aldeia é composta de 30 casas, que formam um círculo de $300 \mathrm{~m}$ de diâmetro. No lado interno do círculo de casas, segue ao redor uma larga rua (rua circular*). No centro, encontra-se uma praça com $60 \mathrm{~m}$ de diâmetro (pátio). De cada 
casa, um largo e reto caminho leva a essa praça (caminho radial), de modo que a aldeia, vista de cima, tem a aparência de uma roda gigante. Estradas na direção dos pontos cardeais prolongam-se diretamente cerrado afora (estradas de corrida); a estrada setentrional tem $17 \mathrm{~km}$ de comprimento [Foto 1].

b) Os Ramkókamekra são divididos em moieties* exogâmicas, matrilineares e matrilocais, das quais uma, Harãkateye, ocupa a parte oeste, e a outra, Kóikateye, a parte leste do círculo de casas.

c) O menino recebe seu nome do irmão ou do primo paralelo de sua mãe, a menina da irmã ou da prima paralela de seu pai.

d) A população masculina divide-se, sem levar em consideração as moieties, da seguinte maneira:

1 Meninos cuja iniciação** ainda não começou.

Os maiores deles se reúnem em uma classe de idade não oficial.

2 Os moços e homens, divididos em quatro classes de idade.

3 Conselho***

e) Somente as quatro classes de idade oficiais são esportivamente ativas e realmente organizadas. Uma classe de idade abarca todos os indivíduos iniciados ao mesmo tempo. Visto que as iniciações se estendem por um espaço de tempo de aproximadamente 10 anos, existe entre as diversas classes uma diferença de idade média proporcional. Após a conclusão do ciclo de iniciação dos jovens de 1924 a 1933, a relação entre as classes de idade era a seguinte: no lado nordeste do pátio estavam os Kra/tãkama, com 54 homens, cuja iniciação terá início em 1934 ou 1935 e será concluída mais ou menos em 1943. Diante deles estavam, no lado noroeste, os Põhitíkama (36 homens), que em 1933 concluíram a última fase de sua iniciação, cuja primeira fase tinha começado em 1924. Ao lado dos Kra/tãkama, no lado sudeste, estava a classe dos Kapranpotíkama, constituída nas iniciações de 1914 a 1923 e que tinha 23 membros. Defronte dela, no lado sudoeste, tinha seu lugar a classe Rópkama, com 21 homens que passaram por sua iniciação no período de 1904-1913, constituindo naquele tempo a classe mais antiga. O Conselho, que senta

\footnotetext{
* N.T. - Nimuendajú usa, no original alemão deste texto, assim como no manuscrito em português (1944:80, 90), " moiety/moieties" em inglês. Decidimos manter esse uso para registrar o modo como o autor manejava o vocabulário antropológico da época.

** N.T. - Nimuendajú fala em “consagração de juventude” (J ugendweihe); decidimos no entanto utilizar o termo " iniciação", preferido pelo próprio autor no manuscrito de 1944.

$* * *$ N.T. - Literalmente, "Senado" (der Senat); optamos por "C onselho", conforme o manuscrito de 1944.
} 
no meio do pátio, era formado pelos 14 sobreviventes de uma classe ainda mais antiga. Se em 1944, a agora não oficial classe de meninos começar seu ciclo iniciatório, ela irá ocupar seu lugar no lado noroeste; a próxima classe entrando no ciclo, em 1954, novamente o fará pelo lado nordeste e assim sucessivamente. Ao mesmo tempo, com o ingresso de uma classe de idade em formação nos lados nordeste ou noroeste do pátio, a classe de idade mais velha dos lados sudeste ou sudoeste, respectivamente, retira-se da comunidade esportiva ativa e seus sobreviventes passam para o Conselho. Por conseguinte, nunca há no pátio mais de quatro classes de idade. Destas, as duas que ocupam o lado oeste são solidárias uma com a outra, e as duas do lado leste igualmente. Essa bipartição das classes de idade em orientais e ocidentais é a mais importante para a corrida de toras [Foto 2].

\section{Figura 1}

Esquema da posição das classes de idade no pátio após o encerramento do ciclo de iniciação da classe Põhitíkama, julho de 1933 (Ramkókamekra)

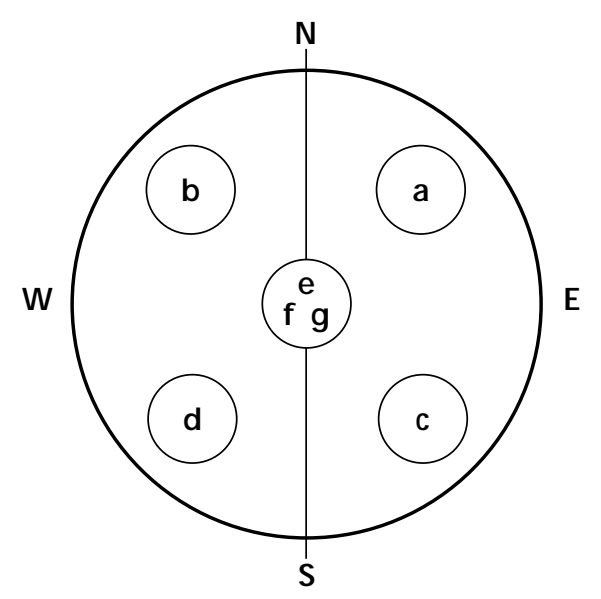

Classes de idade do leste: $\mathbf{5 4}$ homens

a Kra/tãkama (não iniciada, 1934): 31 homens

c Kapranpotíkama (1923): 23 homens

Classes de idade do oeste: $\mathbf{5 7}$ homens

b Põhitíkama (1933): 36 homens

d Rópkama (1913): 21 homens
Conselho: 14 homens

e Kurútkama (1903): 8 homens

f Prókama (1893): 4 homens

g Kukóekama (1883): 2 homens

h ? (1873): extinta

Obs: Entre parênteses, o ano aproximado do término da iniciação de cada classe. 
f) Os ciclos de iniciação dos quais saem as classes de idade organizadas, seguem-se uns aos outros em intervalos de cerca de dez anos (um ano a mais ou a menos não importa; todas as indicações de tempo que faço aqui são apenas aproximadas). Com uma idade média de 10 anos, os meninos são levados pela primeira vez à reclusão, por mais ou menos três meses (ritual do Ketuaye); três anos mais tarde, pela segunda vez, nova reclusão de igual duração (ritual do Pepyé). Após mais três anos é repetida a primeira cerimônia e depois de esta fase ser vencida novamente, repete-se no mesmo prazo também a segunda fase, sempre com os mesmos indivíduos: com isso o ciclo é fechado e, no ano seguinte, poder-se-á começar um novo. Nos dois anos que se estendem entre uma e outra fase da iniciação, comemoram-se à vontade outras grandes festas da tribo: o canto do peixe (Tep-yarkwá), a festa das máscaras dos Kokrít ou o Pep-kahák, igualmente combinadas com reclusão. Nenhuma destas três últimas festas, no entanto, tem a ver diretamente com a iniciação dos jovens; apenas servem para preencher o tempo. (Mas mesmo esse esquema de festas não é seguido rigorosamente.)

g) Cada classe de idade tem, entre outros, os seguintes dignitários principais: um comandante (M ekapónkate)* de uma classe mais velha; um substituto deste (M ekapónkate-kahák), normalmente o mais velho e sensato entre seus contemporâneos; dois líderes de classe (M amkyéti)**, um de cada moiety; duas meninas associadas (M ekuicwé), igualmente uma de cada moiety. [Fotos 3 e 4]

h) Os Ramkókamekra dividem o ano em dois períodos de festas: o primeiro começa com o início da colheita de milho e se estende até o momento em que o sete-estrelo [Plêiades] torna-se visível no céu ocidental depois do pôr-do-sol. Em seguida começa o segundo período ritual, que dura novamente até a próxima colheita do milho. O primeiro período quase coincide com a época da seca e chama-se $\mathrm{Vu}$ /te; o segundo corresponde mais ou menos à época das chuvas, M eipimrák. Todas as cerimônias de iniciação e demais grandes festas da tribo são comemoradas, exclusivamente, durante o período $\mathrm{Vu}$ /té. Vu/té, termo que dá nome ao período, designa duas meninas, uma de cada moiety, em cujas casas maternas se reúnem as classes de idade, onde as meninas servem comi-

* N.T. - Kommandanten. Notar, entretanto, que, no manuscrito de 1944, Nimuendajú glosa mekapónkate por " instrutor" ; na edição em inglês (1946), o termo é traduzido por "instructor, commandant".

** N.T. - Klassenführer. No manuscrito de 1944, o termo mamkyéti é traduzido por " comandante" , mas na edição em inglês este termo é substituído por " líder" . 
da e dançam; as classes de idade orientais são entretidas na casa da Vu/té do oeste, as classes de idade ocidentais na casa das Vu/té do leste. As casas maternas das $\mathrm{Vu}$ /té ficam sempre, aproximadamente, uma defronte da outra.

i) Uma bipartição totalmente diferente domina a estação do ano designada M eipimrák. Ela se estende sobre os aldeões de ambos os sexos, mas também sobre toda a natureza, onde se apresenta da seguinte maneira:

$\begin{array}{ll}\text { Kámakra } & \text { Atúkmakra } \\ \text { Leste } & \text { Oeste } \\ \text { Sol } & \text { Lua } \\ \text { Dia } & \text { Noite } \\ \text { Estiagem } & \text { Chuvas } \\ \text { Fogo } & \text { Lenha } \\ \text { Terra } & \text { Água } \\ \text { Tinta vermelha } & \text { Tinta preta } \\ \text { Etc. } & \text { Etc. }\end{array}$

Também sobre animais e plantas se estende essa bipartição, de que eu já tomara conhecimento em uma outra tribo Jê, os Kaingang. Abrangendo lá, porém, também as duas moieties, entre os Ramkókamekra a bipartição se torna completamente independente delas. A afiliação depende, ao contrário, do nome da pessoa que vem sendo indicada, conforme o item b. Assim, ocorre que de dois irmãos de pai e mãe, um poderá ser Kámakra e o outro Atúkmakra, pois os nomes pessoais nessa tribo não têm relação com a moiety. A despeito disso, acredito que a divisão em Kámakra e Atúkmakra, também nos Ramkókamekra, tenha antigamente coincidido com as moieties. A bipartição nas tribos, no entanto, nada tem a ver com o sexo.

j) Independente da bipartição em moieties, daquela em 2x2 classes de idade e da divisão em Kámakra e Atúkmakra, existe ainda uma quarta bipartição, em 2x3 grupos que se distinguem através da pintura corporal; destes, três têm seu lugar no lado leste e três no lado oeste do pátio: eles são denominados Menkacá e abrangem apenas os homens. A qualidade de membro é transmitida juntamente com o nome, de tio materno para sobrinho. Essa bipartição, contudo, não corresponde em absoluto a qualquer uma das três anteriores. Ela se apresenta, principalmente, quando se trata de cerimônias que envolvem o avunculato. Talvez tenha provindo de uma divisão das moieties em clãs localizados (como, por exemplo, nos Xerénte), antigamente existente e posteriormen- 
te mal-entendida. Os grupos de pintura* do leste recebem o nome de Kóirumenkacá; os do oeste são chamados Harárumenkacá.

\section{Figura 2}

\section{Esquema de posicionamento dos grupos de pintura (Menkacá) no pátio (Ramkókamekra)}

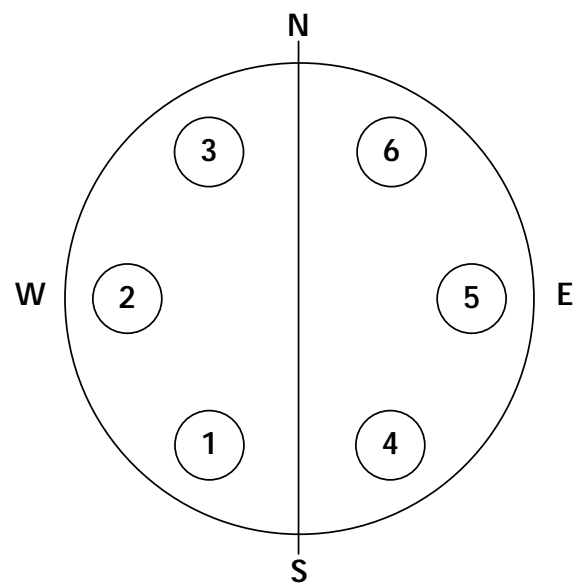

Grupos do Leste (Kóirum-menkacá)

1 Kupẽ (tribo estrangeira)

2 Kétre (papagaio anão)

3 Aucét (tatu)
Grupos do Oeste (Harárum-menkacá)
4 Codn (urubu)
5 Cepré (morcego)
6 Haká (jibóia)

k) Finalmente, existem entre os Ramkókamekra ainda seis sociedades que se apresentam juntas, em grupos de dois ou de três, apenas por ocasião de determinadas grandes festas:

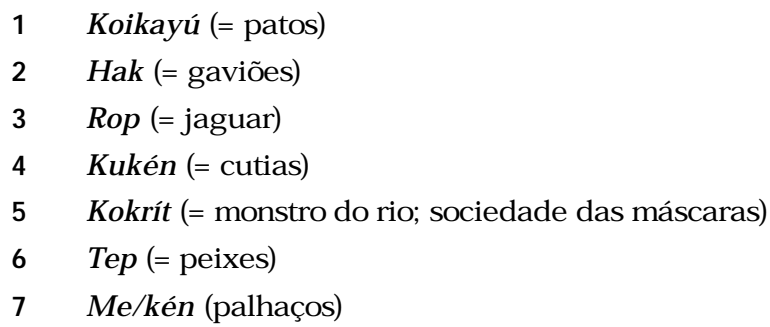


Em todos os casos, com exceção dos Me/kén, a qualidade de membro pode ser transferida do tio materno ao sobrinho; na sociedade dos palhaços, entra quem se sentir qualificado para isso. De cada sociedade fazem parte duas meninas (Mekuicwé); as meninas associadas dos $\mathrm{M}$ e/kén são as duas $V u$ uté. Não pertence a essa classe de sociedades de festa a liga dos Tamhák, que não têm M ekuicwé e cujos membros são dotados de funções sociocerimoniais específicas e, em parte, mágicas. Essa liga remete a um princípio de organização diferente: àquele referente à descendência de diversas outras tribos, cujos remanescentes têm sido adotados pelos Ramkókamekra, há muito estabelecidos. As sete sociedades de festa são em parte solidárias e em parte adversárias, opondo-se, segundo cada festa, nos seguintes agrupamentos: no fim de cada uma das festas Vu/té: Rop versus Kukén; na festa de máscaras Kokrít: Rop versus Kukén e Kokrít; no Tep-yarkwá: Tep versus M e/kén; na festa Pepkahák: Koikayú versus Hak (+ Me/kén + Tamhák + Pep-kahák).

Todas as organizações aqui enumeradas mantêm, de algum modo, como veremos, relações com a corrida de toras. De acordo com a ocasião da festa, as equipes participantes compõem-se da seguinte maneira:

1 Durante o período Vu/té, correm em geral as duas classes de idade ocidentais contra as duas orientais. Essa organização será mantida mesmo se forem comemoradas nessa época as cerimônias de iniciação, seja o Ketuaye ou o Pepyé.

2 A corrida Para-kahák, no começo da reclusão dos Pepyé, na qual os grupos de pintura do leste (Kóirumenkacá) jogam contra os do oeste (Harárumenkacá), representa uma exceção [ao dito acima].

3 Durante toda a festa Pep-kahák, a sociedade Koikayú corre contra a sociedade Hak. No fim da solenidade, os Me/kén, os Tamhák e até mesmo os Pep-kahák passam para o lado dos Hak.

4 Durante a solenidade Tep-yarkwá, que pode ser comemorada de duas maneiras diferentes: ou os grupos de pintura orientais (Kóirumenkacá) correm contra os grupos ocidentais (Harárumenkacá), ou, na forma mais simples, as classes de idade do lado leste contra as do lado oeste.

5 Durante a festa das máscaras Kokrít, os membros desta sociedade correm junto com os da sociedade Kukén contra os Rop.

$6 \quad$ Kukén e Rop formam também as equipes de corrida na festa final de cada período $\mathrm{Vu}$ /té, na qual os Me/kén apóiam os primeiros.

7 Durante a estação M eipimrák, os Kámakra correm contra os Atúkmakra. 
Totalmente diferente, e muito mais simples que entre os Ramkókamekra, é a composição das equipes nos Timbira ocidentais, os Apinayé. É preciso considerar, porém, que dado o contingente populacional diminuto destes últimos (em 1824, eles somavam 4.200; em 1928, no entanto, eram apenas 150 cabeças), uma organização tão complicada e variada como a dos seus parentes orientais, não seria mais viável. Todavia, de fato, toda a organização cerimonial dos Apinayé parece ter sido mais simples desde o princípio, na medida em que atribuíram às moieties funções para as quais os Ramkókamekra têm uma bipartição especial. Não apenas na corrida de toras mas, sobretudo, em todas as atividades esportivas exercidas por suas equipes, os Apinayé sempre se dividem nos dois partidos Katám e Vanmégn. Estes não são mais do que mera reunião dos membros masculinos esportivamente ativos das moieties Katám, do oeste, e Vanmégn, do leste. Nos primeiros, as pontas das testeiras são tingidas de preto, nos demais de vermelho.

Esses dois nomes são conhecidos também nos Ramkókamekra: aqui se denomina Vanmẽye o partido Kámakra, e Ka/támye o partido A túkmakra, da organização da estação chuvosa. Igualmente, pertencem aqui aos primeiros, o leste (veja item i) e a tinta vermelha, e aos últimos, o oeste e a tinta preta. Mas esses partidos não são de maneira alguma idênticos às moieties, mesmo se a bipartição se estende sobre ambos os sexos e não apenas sobre o masculino, como entre os Apinayé. A suposição, já expressa acima, com respeito à identidade original entre a bipartição da estação das chuvas e a divisão em moieties, no caso ramkókamekra parece ainda mais provável à luz dessa comparação com as condições nos Apinayé.

Corridas de toras são realizadas pelos Timbira, portanto, ao longo do ano inteiro, ainda que, nos Ramkókamekra, a composição das equipes seja diferente conforme a ocasião. No período $V u$ uté, que representa o tempo propriamente dito das grandes festas, as corridas são freqüentes e importantes, podendo excepcionalmente ocorrer até três vezes por dia. A idade dos participantes oscila entre 15 e 55 anos. O caráter meramente esportivo fica ainda mais claro, pelo fato de que, em seguida às grandes corridas de toras, se realizam amiúde uma corrida de estafetas dos mesmos partidos pela rua circular ou competições de pares no diâmetro periférico da aldeia.

A corrida de toras pode ser efetuada em dois tipos de pistas. O habitual é que parta do lugar da produção das toras em direção à aldeia, utilizando o máximo possível as mencionadas estradas de corrida, que irradiam da aldeia para os pontos cardeais e que são preparadas pelos ho- 
mens em reclusão durante o Pep-kahák. O comprimento da pista varia bastante. Oscila entre pouco mais que $1 \mathrm{~km}$ e $12,5 \mathrm{~km}$ - comumente tem mais ou menos $3 \mathrm{~km}$ de comprimento. Algumas vezes a corrida é feita na rua circular, de quase $1 \mathrm{~km}$ de comprimento, que é percorrida até duas ou três vezes. Tais corridas, entretanto, se realizam em geral somente em seguida a uma corrida de fora para a aldeia; jamais se começa uma corrida na rua circular com toras já usadas, para depois buscar novas toras de fora.

As toras de corrida usuais chamam-se Pára* e são peças cilíndricas do tronco da palmeira buriti (M auritia flexuosa), com cerca de um metro por $40-50 \mathrm{~cm}$ de diâmetro. Elas são trabalhadas nas bordas do corte para que se consiga segurá-las melhor. O peso de cada uma dessas toras de corrida, calculo em aproximadamente $100 \mathrm{~kg}$; na maioria das vezes, no entanto, são um pouco mais leves. Nos Krĩkateye, cheguei a ver toras de corrida de tamanho gigantesco que, porém, foram escavadas de ambos os lados, até uma parede divisória de $5 \mathrm{~cm}$ de espessura. Semelhantes, são as que os A pinayé usam em uma corrida, por ocasião do encerramento do luto pela morte de um adulto. As toras prontas são sempre examinadas por um velho experiente que manda cortar um pedaço, se pesadas demais, ou colocá-las na água, se consideradas leves.

Uma variante especial de toras de corrida é a já mencionada Parakahák, produzida pelos Ramkókamekra no início da reclusão da Pepyé. São feitas da madeira de uma árvore do cerrado chamada maria mole [em português no original], com $50 \mathrm{~cm}$ de comprimento e um pouco menos grossa, destacando-se por cabos que sobressaem da parte central do corte, nos dois lados, em direção ao eixo, cabos que não se encontram nas toras de corrida habituais. A pista de corrida, nesse caso, tinha apenas pouco mais de $1 \mathrm{~km}$.

Cheguei a ver um outro tipo de tora de corrida (Para-kacáre) no primeiro dia da cerimônia final do Ketuaye. Eram cilindros de madeira com $47 \mathrm{~cm}$ de comprimento e $7 \mathrm{~cm}$ de espessura. Seu peso era tão ínfimo que não podia ser considerada como uma carga na corrida. As classes de idade orientais corriam com isso contra as ocidentais, saindo do lugar da produção em direção à aldeia, seguindo-se uma segunda corrida na rua circular com toras pesadas já usadas.

Às vezes, quando estão juntos, um pequeno número de homens, de volta de um empreendimento coletivo mais demorado fora da aldeia, que- 
rendo fazer sua entrada na forma de uma corrida de toras, simplesmente corta dois pedaços de galhos que correspondam às suas forças. Pequenas corridas desse gênero ocorrem com relativa tranqüilidade e sem chamar a atenção, mas ainda assim atraem sempre à porta das casas, um grande número de espectadores, interessados na chegada dos corredores na aldeia. Por outro lado, extremamente impressionantes são as grandes corridas, principalmente na forma como são realizadas no fim de uma festa da tribo, sobretudo da cerimônia do Pepyé, nas quais toda a aldeia, por assim dizer, está em atividade.

A uma distância conveniente da aldeia, na mata ciliar de um riacho onde existam palmeiras buriti, as duas toras de corrida são fabricadas pelo partido desafiante, sendo levadas, logo que prontas, para uma das estradas de corrida ou, na maioria dos casos, para um dos caminhos que desembocam nessa estrada. Ali, limpam um lugar de mais ou menos 6 $\mathrm{m}^{2}$, onde deitam as toras lado a lado, a uma distância de 1,5 m uma da outra, em cima de folhas, a fim de não sujá-las, sempre com o eixo em direção à estrada. Os A pinayé, na maioria dos casos, não colocam suas toras no chão, mas sim sobre um par de forquilhas com 1,5 $\mathrm{m}$ de altura cada uma. Nessa tribo, as toras são às vezes enfeitadas com a devida pintura relativa aos Katám e Vanmégn. [Foto 5]

Em uma corrida especialmente solene, com toras gigantescas (Parakapé), que faz parte da cerimônia Roród dos Apinayé, assisti a um acontecimento digno de nota: quando, acabada a pintura, as duas toras de corrida foram deitadas ao chão, os meninos e meninas maiores tiveram de se apresentar ao lado delas em uma fila, junto a seus padrinhos e madrinhas. Em seguida, o condutor de festa da moiety leste se pôs diante da fila, com um açoite de folhas de palmeira piaçava [em português no original: piaçaba] trançadas, enquanto o da moiety oeste examinava os órgãos genitais dos meninos e meninas um após o outro. Ao encontrar sinais de masturbação, batia com o punho fechado nas duas coxas do culpado, empurrando-o para fora da fila com um golpe nas costas e arrancando-lhe os cabelos da nuca. O punido precipitava-se a uma certa distância até uma árvore candeia (que era marcada para esse fim com cortes de faca), trincava um pedaço da casca, mastigava-a e a esfregava nas suas costas. Quando voltava, recebia do condutor de festa da moiety leste alguns golpes com o açoite de piaçava. No lugar das crianças, submetiam-se às vezes à punição os padrinhos e madrinhas destas.

Os A pinayé chamavam essa cerimônia de mekamicód. Declaravam que a masturbação devia ser punida porque enfraquecia o jovem, tornando-o incapaz para a corrida de toras. Reconhecia-se o menino culpa- 
do quando o prepúcio se deixava arregaçar sobre a glande. Através de que sinais eles julgavam as meninas não sei; apenas me disseram que o reconheciam através do aspecto das partes genitais.

Os Apinayé vestem nas corridas de toras cintos de barbantes de algodão trançados, dos quais pende, na anca esquerda, um bordado retangular de miçangas com penas e pendentes de matraca, feitos de unha de veado* e conchas. Essa tribo também tem um instrumento musical próprio - um pequeno clarinete feito de bambu com uma cabaça acústica (me-õ-i-ratág-re) - usado exclusivamente na corrida, ao lado do qual são soprados os trompetes e flautas também utilizados na dança. Os pendentes de cinto dos Ramkókamekra são muito menos vistosos. Nas corridas, os A pinayé só utilizam trombetas e suas pequenas ocarinas [em português] de cabaça. Ambas as tribos enrolam o pulso com cordões de algodão, como proteção contra ferimentos no canto da tora de corrida. Os A pinayé portam nas competições testeiras feitas de pínulas de palmeira babaçu; os Ramkókamekra fazem-nas de fibras de buriti, fabricando também lençóis, faixas e cintos do mesmo material; nas testeiras e cintos costumam prender compridas caudas de palha. Em uma corrida solene, ao final do Ketuaye, os homens amarram o cabelo da nuca com um leque de palha, do mesmo modo que teriam feito nas expedições de guerra. [Fotos $6,7,8,9,10,11,12$ e 13]

Para a corrida Para-kapé, os A pinayé colam no corpo uma lã esbranquiçada raspada das hastes de folhas novas da palmeira pati; os Ramkókamekra às vezes vestem uma pintura negra para a corrida. A tinta é obtida da seiva leitosa de uma árvore do cerrado (Castilloa sp.) misturada com pó de carvão. Nas grandes corridas de toras compete à menina se prover com cabaças cheias d'água de beber, agüentar o passo dos corredores e servi-los com a mesma.

Às vezes, os dois partidos se reúnem junto às toras prontas, colocando-se cada um do lado que lhe cabe. Na maioria dos casos, porém, o partido desafiante vem primeiro, e seus adversários aparecem bem mais tarde, chegando lentamente sob o sopro das trombetas. Assim que ficam à vista, os membros do partido desafiante se põem atrás das toras de corrida e começam a cantar, batendo palmas lentamente. Tendo o partido adversário se aproximado mais ou menos 40 ou $50 \mathrm{~m}$, eles cantam erguendo as mãos e batendo os pés até que aquele tenha alcançado as toras de corrida. Logo, então, dois homens de cada equipe apanham a tora de cor- 
rida correspondente e colocam-na sobre os ombros de um terceiro, que imediatamente se põe a caminho da aldeia, sendo seguido e cercado pelo bando ruidoso dos seus companheiros. Procura-se sempre como primeiro carregador, um dos mais competentes corredores da equipe, para se ganhar logo de início uma vantagem encorajadora.

Logo começa uma carreira louca: gritando e incitando, soprando trombetas e pífaros, os índios pulam como veados, com enfeites de palha esvoaçando, sobre moitas de capim e pequenos arbustos, à direita e à esquerda da vereda onde correm os carregadores das toras. Depois de cerca de $150 \mathrm{~m}$, um outro passa bem perto do carregador que, sem parar a corrida, transfere a tora para o ombro do primeiro com um giro elegante do corpo, e tudo continua sem a menor interrupção. Destarte, a corrida segue barulhenta, debaixo do sol ardente da estepe sem sombra, colina abaixo, atravessando a água dos riachos e subindo do outro lado, novamente, na areia solta e ardente, onde o pé não consegue se firmar. Logo os velhos e as mulheres que têm de carregar crianças ficam para trás, se já não partiram um pouco antes para deixar a corrida e passar furibundos por eles um pouco mais adiante. Um novo substituto da equipe corre e passa perto do carregador, aliviando-o da tora cada vez que a velocidade ameaça diminuir. Pode-se ver aí como os líderes de classe e aqueles que prezam sua fama de bons corredores, fazem esforços desesperados; após alguns quilômetros, entretanto, o grupo de corredores ofegantes e banhados de suor é visivelmente menor. Sua gritaria excitante torna-se mais rouca e entrecortada, assumindo por fim um tom atormentado. Meninas ágeis e ligeiras servem-lhes, enquanto correm, um gole d'água da cabaça. Ninguém, contudo, pode libertar-se da tora a fim de parar e descansar, por maior que seja a vantagem que já se tenha da equipe adversária. Por fim, aparece a aldeia lá no alto da elevação. Empregando a derradeira força, segue-se pela arenosa encosta acima. Ninguém mais está em condições de carregar a tora por mais de trinta metros: precisam continuamente se revezar. Finalmente, os corredores aparecem entre as casas na rua circular, que seguem até chegar defronte da casa da sua menina $\mathrm{Vu}$ /té, ou então tomam, se as equipes forem compostas por grupos de pintura, o caminho radial mais próximo em direção ao pátio: a tora cai estrondosamente no chão. [Foto 14]

Retardatários ofegantes do próprio partido estão chegando. Depois vem a outra equipe com sua tora de corrida, que deixam cair ao lado. Arfando miseravelmente, com os membros tremendo, o melhor corredor está sentado em sua tora enquanto um velho com cara de perito lhe massageia braços, pernas e corpo. Sossegam apenas por um instante. Depois, 
uma equipe segue, naturalmente andando a trote, para a casa do seu antes melhor corredor, falecido há um ano em uma viagem, celebrando ali uma lamentação pelo morto. E depois - para ninguém pensar que esse pouco correr já os tivesse exaurido! -, levantam mais uma vez as toras e correm com elas na rua circular, ou então se apresentam para a corrida de estafetas pela mesma via ou para uma competição de corrida dois a dois, por trás das casas, da residência de uma $\mathrm{Vu}$ /té à da outra. Somente depois vão tomar banho. Apesar do esforço quase sobrenatural não vi nem ouvi que alguém tivesse sofrido graves lesões pela corrida de toras; o banho depois também não faz mal à ninguém. Por outro lado, ocorre uma série de leves contusões nos pés por causa de cepos e espinhos.

E eis agora o que um civilizado não compreende nunca e pelo que repetidamente imputa ao esporte desses índios motivos correspondentes à sua própria mentalidade: nenhuma só palavra de reconhecimento para os vencedores ou para os que empregaram todas as forças para resistir até o fim, nenhuma só palavra de censura contra os vencidos e retardatários. Não se pode ver nem rostos amofinados, nem triunfantes, pois, para os Timbira, o esporte é a finalidade em si, e não um meio para a satisfação de sua vaidade pessoal. Cada um fez, correspondentemente às suas forças, todo o possível. Isto basta. Somente se tornaria alvo de desprezo e de escárnio aquele que tentasse safar-se da corrida de toras por preguiça. A expressão "cukaká" = mandrião é um grave insulto, principalmente se for aplicado por uma mulher a um homem.

Os melhores corredores (me/hi-túi) são vistos e admirados como tais, sem ter, no entanto, nenhum privilégio. Recebem um cinto trançado de algodão, de dois dedos de largura, com um pendente de matraca (cu) que, especificamente, deveria ser composto do casco da anta. Hoje, porém, com a anta quase totalmente exterminada na área dos Ramkókamekra, está sendo substituído por pequenas cabaças (lagenaria), casco de veado e bico de avestruz. Vestem esse cinto, em geral, nas corridas de toras solenes. Na véspera de tais corridas, realizadas durante o período $\mathrm{Vu} / \mathrm{te}$, as equipes se reúnem nas casas de suas meninas $\mathrm{Vu} / \mathrm{te}$, de onde, ao mesmo tempo gritando e parando freqüentemente, seguem até o pátio, para ali se sentarem em duas filas paralelas, uns diante dos outros. Os M e/hi-túi sentam-se com os seus cintos de chocalhos enrolados nas mãos, em frente à fila dupla, e lentamente começam a bater com isso o ritmo no chão, enquanto todos cantam, a meia voz, duas canções.

Cheguei a ver algo semelhante também entre os Apinayé, onde na noite anterior à corrida Para-kapé, um índio, sentado sobre uma esteira entre duas mulheres no pátio, com a fronte virada para o oeste, cantava 
batendo o ritmo na esteira com o cinto de chocalho enrolado. A cada canção, seguia-se por parte dos outros presentes um animador "tyu" $(=\mathrm{cu}=$ cinto de chocalho?). Essas canções, que levavam o nome Kukén (cutia), duravam das 9 horas da noite até as 5h30 da manhã.

Em uma grande corrida, custa alcançar com a vista o rendimento de cada um. Os líderes de classe bem que procuram regular o trabalho a ser realizado, mas pode-se facilmente imaginar que um bom corredor se canse excessivamente logo no princípio ou em um trecho especialmente desfavorável do caminho, de maneira tal que acabe por se ver entre os retardatários, enquanto um menos bom consegue poupar suas forças para o final da corrida. Com o entusiasmo e a exaltação gerais, que vêm a ser acrescentados deliberadamente pela barulheira, resta, portanto, pouco espaço para uma administração fria e calculada das forças.

Quando, entre os A pinayé, as primeiras corridas de toras dos jovens guerreiros se realizam no fim da segunda fase da iniciação, então, os líderes das moieties observam se, por acaso, algum deles está com os joelhos tremendo ao chegar à meta. Se esse for o caso, isso quer dizer: “Ele não presta para corrida: Tem sangue demais!" . Mandam, então, o jovem, que não pode ter tido ainda relações sexuais, buscar um pedaço de um formigueiro de uma espécie de formigas pretas muito picantes que fazem ninhos nas árvores. O julgado fraco ainda participa, na manhã seguinte, de mais uma corrida de toras; depois, o escarificador (me/kupén-cwun; kupén = arranhar) leva-o para um lugar com água, coloca-o com o rosto voltado para o leste e com seu instrumento, que consiste de uma série de dentes de rato embutidos em um pedaço de casca de cabaça, aplica longos arranhões na parte interna das coxas do jovem. Depois, vai para casa, deixando o rapaz sozinho. Este limpa o sangue com folhas (costelas de folha da bacaba) e queima o formigueiro, esfregando o carvão deste nos arranhões sangrentos. Permanecerá, então, durante cinco dias em casa; depois, volta de novo ao riacho, queima as folhas da palmeira pati e o capim do cerrado, esfrega-se com os restos queimados e folhas e, em casa, passa almécega misturada com urucu, nos arranhões (cf. Oliveira 1930:65-66).

Entre os Ramkókamekra, por outro lado, estranhamente, nada, absolutamente nada, é feito para melhorar os baixos rendimentos individuais nas corridas de toras. Nas corridas dessa tribo, é tudo completamente diferente. Isso eu constatei na conclusão da cerimônia do Pepyé, quando o comandante substituto chegou correndo atrás do último retardatário, batendo-lhe continuamente com galhos de pau-de-leite nas pernas. Seu semblante aborrecido expressava claramente quanto lhe pesava a res- 
ponsabilidade de ter tal sujeito frouxo na sua classe de idade. Seu mau humor desafogou-se, então, em uma longa e veemente descompostura, dirigida aos companheiros de classe reunidos em volta dele em um semicírculo, na qual explicava o resultado desfavorável da corrida como conseqüência do desrespeito ao regulamento de reclusão, lamentando-se amargamente da desobediência nesse sentido. Quando, finalmente, deu um passo para trás, o velho [comandante] ainda passou uma segunda descompostura nele e em seus camaradas. (Com os Apinayé nunca acontece uma coisa igual a essa depois de uma corrida de toras, seja qual for o resultado.)

Parece que antigamente eram disputadas corridas de toras até entre membros de tribos diferentes, nas quais chegavam a eclodir brigas perigosas, pois se levava armas clandestinamente, que eram escondidas algures no caminho (o que em corridas entre membros da mesma tribo, nunca aconteceu). Contaram-me casos que parecem ter se passado há uns 40, 50 anos atrás: os naquele tempo ainda muito numerosos Apányekra, às vezes, vinham fazer uma visita aos ramkókamekra. Faziam toras de corrida em uma distância conveniente da aldeia dos últimos, desafiandoos. Dado que as duas tribos nunca simpatizaram muito uma com a outra, chegavam a acontecer pancadarias sangrentas no final da corrida.

Em certas ocasiões são realizadas, também, corridas de toras para meninas maiores e mulheres jovens. Todavia, enquanto o número de corridas realizadas anualmente pelos homens ramkókamekra ultrapassa certamente uma centena, conheço apenas as seguintes ocasiões em que corridas de mulheres e meninas fazem parte do programa:

1 Na solenidade final do período anual Vu/té.

2 e 3 Na solenidade final de cada uma das fases da iniciação, tanto do Ketuaye, como do Pepyé.

$4 \quad$ Na solenidade final da festa Pep-kahák.

Nos três últimos casos, a cerimônia é absolutamente idêntica: um porco caititu (Dicotyles torquatus), criado com esse objetivo, é abatido com uma borduna e todos os companheiros da festa seguem com o animal morto para um acampamento cerca de $6 \mathrm{~km}$ no cerrado estepe, onde estão sendo preparados e distribuídos enormes bolos de carne. Nas proximidades do acampamento, dois pares de toras de corrida estão colocados à disposição: o das mulheres e meninas, que é sempre um pouco mais leve que o dos homens, encontra-se no caminho antes do último. A volta dos convivas, após o festim, sucede então na forma de uma grande corri- 
da. Contudo, os homens não apostam corrida com as mulheres, e sim cada sexo corre separadamente em duas equipes. Deixam para as toras de corrida das mulheres e meninas uma vantagem; entretanto, elas são logo ultrapassadas pelas dos homens e jovens. Se os homens, nas corridas desse tipo, são divididos por classes de idade (oeste e leste), as mulheres não dispõem de modo algum de uma organização correspondente, dividindo-se segundo a organização dos homens: as parentas (matrilineares) dos membros das classes de idade leste formam um partido, as dos membros das classes de idade oeste o outro.

Nas corridas de toras ao fim do período $V u$ /té, os participantes são divididos em Kámakra e A túkmakra, dado que esta bipartição se estende a ambos os sexos: os Ka-kwei formam um partido feminino e os Atúkmakra o outro. A divisão ocorre sempre em um lugar cerca de $500 \mathrm{~m}$ da aldeia, onde uma parede de palha de palmeira foi levantada cruzando a estrada de corrida. Os Kámakra reúnem-se no lado voltado para a aldeia, os Atúkmakra no outro, pois Kámakra quer dizer "o povo da pátio", e Atúkmakra "o povo de fora".

O peso das toras feitas para as mulheres e meninas quase sempre vai além de suas forças. Em quatro das cinco corridas desse gênero a que assisti, elas não conseguiram, apesar do esforço realmente desesperado, levar somente por si mesmas suas toras para a aldeia, especialmente por não superarem a areia pisada da última subida. Na solenidade final do Ketuaye, foram ajudadas pelos rapazes maiores entre aqueles que estavam terminando sua iniciação; nas outras, alguns dos homens, depois de terem feito chegar as suas próprias toras, voltaram para trás e ajudaramnas. Como melhor corredora foi considerada uma certa moça, Yarpót, de cerca de 18 anos de idade, que em 1933 se casou com o melhor corredor da classe de idade recentemente iniciada. Mulheres que já se tornaram mães não participam mais ativamente nas corridas de toras. [Foto 15]

Somente a primeira corrida do período M eipimrák (estação das chuvas) acontece do modo acima descrito, com enormes toras de corrida, como a do período Vu/té. Entra, então, em vigor a seguinte regra: de início, os Kámakra, como partido desafiante, fazem o primeiro par de torinhas, que não têm mais que $5 \mathrm{~cm}$ de diâmetro por $2,5 \mathrm{~cm}$ de largura. A cada corrida cresce o tamanho das toras até que, depois de cerca de duas semanas, estas tenham alcançado um volume normal. Em seguida, parte o desafio dos A túkmakra, que fazem seu primeiro par de torinhas de corrida ainda mais finas, porém um pouco mais compridas $(15 \mathrm{~cm})$, aumentando-as a cada nova corrida, até que se alcance a medida normal. O primeiro par de torinhas de corrida dos Kámakra possui o man- 
to* decorado com riscos longitudinais vermelhos, e cada um dos cortes tem uma mancha vermelha concêntrica. As dos Atúkmakra exibem, em cada corte, uma tira negra. [Fotos 16 e 17]

Os meninos que ainda não entraram na iniciação fazem para si duas pequenas toras de corrida junto da aldeia, e organizam então as suas corridas de toras na rua circular; nas corridas de toras dos homens e jovens, esses meninos correm diligentemente ao lado deles.

Cheguei a observar a eliminação da classe de idade mais velha da comunidade esportiva ativa na cerimônia do Pepyé de 1933. Em virtude da instalação definitiva da classe Kra/tãkama, ao fim daquela iniciação, no lado nordeste do pátio, a classe Kapranpotíkama, cerca de 20 anos mais velha, que antes ocupava aquele lugar, foi movida para o sul, na praça sudeste, e os oito sobreviventes da classe Kukrítkama (por sua vez 20 anos mais velhos que os Kapranpotí), anteriormente assentados ali, passaram para o Conselho. Todos os seus dignitários tinham há muito morrido. Nove dias após o fim da solenidade Pepyé, propriamente dita, todos os sobreviventes se reuniram e participaram pela última vez, de forma ostensiva e com dedicação, em uma das corridas de toras diariamente realizadas entre as classes de idade orientais e ocidentais. Com isso renunciaram formalmente ao seu direito pelo lugar sudeste; de fato já o tinham feito há muito tempo e se sentado no Conselho.

Além das corridas de toras aqui descritas, pertencentes à área do atletismo, existem ainda outras, em um certo sentido simbólicas, que, como as corridas inaugurais dos Kámakra e A túkmakra, realizam-se com toras cujo peso não tem valor do ponto de vista atlético, e que por causa disso constituem competições à maneira das corridas de estafetas com torinhas simbólicas. Essas corridas se realizam sempre e apenas no fim de cada uma das duas fases da iniciação, o Ketuaye e o Pepyé. As torinhas, com cerca de $25 \mathrm{~cm}$ de comprimento, sempre pintadas de vermelho com urucu, chamam-se Para-re, pesando cada uma cerca de 245 gramas, e são uma versão estilizada das grandes toras com cabos, Parakahák, usuais no início da solenidade Pepyé. Elas são as toras de corrida das almas dos mortos. [Foto 18]

O objetivo original de todo Ketuaye era levar os meninos à útil, porém perigosa para os inexperientes, comunhão com as almas dos mortos (me-karõ = alma de morto, sombra, imagem, bordunas). Isto se deduz não apenas da lenda sobre a origem dessa iniciação, segundo a qual as 
diversas cerimônias teriam sido aprendidas com as almas dos mortos, mas também de atos como a alimentação dos meninos com alimentos invisíveis. A idéia original era evidentemente que, através do próprio canto executado pelos Ketuaye, as almas dos mortos se aproximassem e adentrassem no corpo dos meninos, que agora agem como as próprias almas até que sejam separados delas por meio de banhos e açoitamentos. Em virtude disso, existem também as corridas com as torinhas das almas dos mortos, as Para-re. Nenhum dos Ramkókamekra de hoje, no entanto, compreende esse contexto perfeitamente. De alguns, pode-se obter explicações e alusões que comprovam inteiramente a opinião acima; outros buscam muitas explicações racionais e terapêuticas para cada caso, ficando por causa disso claro seu caráter secundário. Entre os Apinayé, antes com tendências um pouco mais religiosas, pelo contrário, falta completamente o motivo da comunhão entre os meninos e as almas dos mortos durante a iniciação.

Em uma manhã, encerrada a reclusão do Pepyé, os homens, divididos nas 2x3 classes de pintura, apresentaram-se no pátio. De modo misterioso, um deles descobrira as duas Para-re que haviam sido enterradas na margem da praça, colocou-as debaixo do braço e, cercado pelos jovens Pepyé e seguido por todos os grupos, saiu da aldeia, distanciando-se quase $1,5 \mathrm{~km}$. Os Pepyé se dispersavam como estafetas ao longo da estrada e apenas seus dois líderes de classe (M amkyeti), com os enfeites de occipício cheios de penas da cauda de arara (panyapí) na cabeça, seguiam com os outros até o ponto de partida da corrida, onde, com as Para-re nas mãos, ajoelhavam e cantavam. Começava então a corrida de todos, com as duas torinhas, de volta à aldeia - os membros do grupo de pintura oeste tinham de correr do lado direito, os do leste do lado esquerdo da estrada de corrida. Diante da entrada da aldeia, posicionaram-se no meio da estrada as duas M ekuicwé, junto com as antecessoras da iniciação anterior, por trás de grandes salvas cheias d'água, perfumadas com as folhas da árvore negra-mina [em português no originall pulverizadas. Duas delas seguravam ramos de pau-de-leite nas mãos. As torinhas foram postas no chão na frente delas e cada um dos corredores, ao chegar, dava um passo à frente, as mãos apoiadas nos joelhos, diante das moças de sua moiety, das quais uma lhe despejava água sobre a cabeça e as costas, e a outra depois lhe aplicava uns golpes com os ramos. Por fim chegavam, montados nos ombros de homens que estão para com eles na condição de Hapín [amigo formal], os dois líderes de classe dos Pepyé, que, sem receber lavagem e açoitamento, eram deixados diante das moças. [Fotos 19e 20] 
Na cerimônia do Ketuaye, antes de nascer o sol, foi colada nos meninos, penugem branca de gavião, cada um em seu devido grupo de pintura no pátio, onde ardiam imensas fogueiras, que, segundo me disseram expressamente, haveriam de afastar, por enquanto, as almas dos mortos. Três a três, os seis grupos se juntaram de modo cerimonial às duas equipes de corrida dos Kóirumenkacá e Harárumenkacá. Encontraram as torinhas escondidas na terra no meio da praça e correram com elas para fora da aldeia. Uma parte dos meninos Ketuaye, julgados como insuficientemente fortes e resistentes, voltou, porém, tomando posição novamente no pátio, em uma fila atrás das moças M ekuicwé com suas salvas d'água e ramos. Um a um, então, apresentaram-se diante das moças, sendo regados com água e açoitados. Assim que elas terminaram, os corredores Para-re, chegaram impetuosamente, deitaram as torinhas diante delas e foram tratados de modo idêntico. $\mathrm{O}$ dois líderes de classe com seus enfeites de penas na cabeça vieram, como sempre, cavalgando nos ombros de seus Hapín. Um dos meninos Ketuaye, que tinha participado da corrida, chegou completamente perturbado e exausto, e foi logo submetido, pelo condutor de toda a iniciação, a um tratamento especial. Quando indaguei o que havia com ele, responderam-me que as almas dos mortos o teriam tratado muito mal. [Foto 21]

As pequenas torinhas Para-re com 2,5 cm de comprimento servem de enfeite. Elas pendem, em pares ou em feixes completos, dos colares e faixas sobre o peito. Qualquer significado que tenham tido esses enfeites, os Ramkókamekra de hoje o desconhecem. Digno de nota, além disso, é que vi torinhas Para-re caracterizadas, como as bonecas das menininhas, por seios de cera fixados, cintas e cordas de anca, como homem e mulher. Voltarei a falar disso adiante. [Foto 22]

Dada a predileção dos Timbira pela corrida de toras, encontram-se espalhadas em grande número, por toda parte em suas aldeias, velhas toras de corrida. Quem quiser pode pegá-las e usá-las à vontade. Dentro e fora das casas, encontram-se, na sua maioria, inteiras e mais raramente partidas pela metade, ao longo das paredes, para servir de assento. Usamnas também de bom grado como proteção contra os porcos que andam soltos. Para isso, põem-nas ante o dormente da porta e no cercado em volta de novas arvores frutíferas e demais plantas, junto às casas que se pretende proteger. A té as covas atrás das casas são cercadas desse modo contra os porcos. A madeira fibrosa e suculenta seca rapidamente e apodrece; posteriormente a velha tora é cortada e usada como lenha. [Foto 23]

A corrida de toras parece ser o esporte nacional de todas as tribos timbira. Eu mesmo cheguei a assisti-la umas 150 vezes entre os Ramkó- 
kamekra, umas 30 vezes nos Apinayé e 2 vezes entre os Krahó. Vi toras de corrida nas aldeias A pányekra, Krikkateye e Pukópye. Nos Timbira de Araparytiua, no médio rio $G$ urupi, fiquei sabendo que eles ainda a praticavam até 1913. Entre os G aviões selvagens, uma expedição punitiva encontrou em 1931 duas largas estradas retas, aparentemente estradas de corrida, e um cinto de chocalho com unha de anta, como costumam portar os melhores corredores. Entre os Cákamekra, hoje em dia extintos como tribo autônoma, as corridas de toras têm o mesmo papel que nos Ramkókamekra, segundo os depoimentos dos poucos sobreviventes. Pohl (1832:205) menciona uma corrida de toras da hoje igualmente extinta tribo timbira dos "Poracramacrans" (= Põrekamekra); ele, lamentavelmente, não a viu com os próprios olhos. Um círculo próprio para isso fora formado na praça da aldeia: "Nesta dança eles se servem de toras de $3^{1 / 2}$ côvados de comprimento e $1^{1 / 2}$ sapato de diâmetro com peso de 4-6 arrobas [que ele obviamente viu] que foram carregadas nos ombros, sendo jogadas pelos dançarinos de um ao outro". Lançar e pegar, na dança, toras de 87 kg não devia ser tão simples como na descrição de Pohl.

Não tenho nenhuma prova da prática da corrida de toras apenas para os diminutos grupos de remanescentes das tribos timbira dos Krẽyé de Cajuapára e dos Kukóekamekra e Krẽyé de Bacabal, os quais também nunca visitei em suas aldeias. No entanto, é provável que também eles pratiquem esse esporte, ou pelo menos o tenham feito quando ainda dispunham para isso do número necessário de homens, o que hoje não é mais o caso. 
Mapa: Distribuição da corrida de toras*

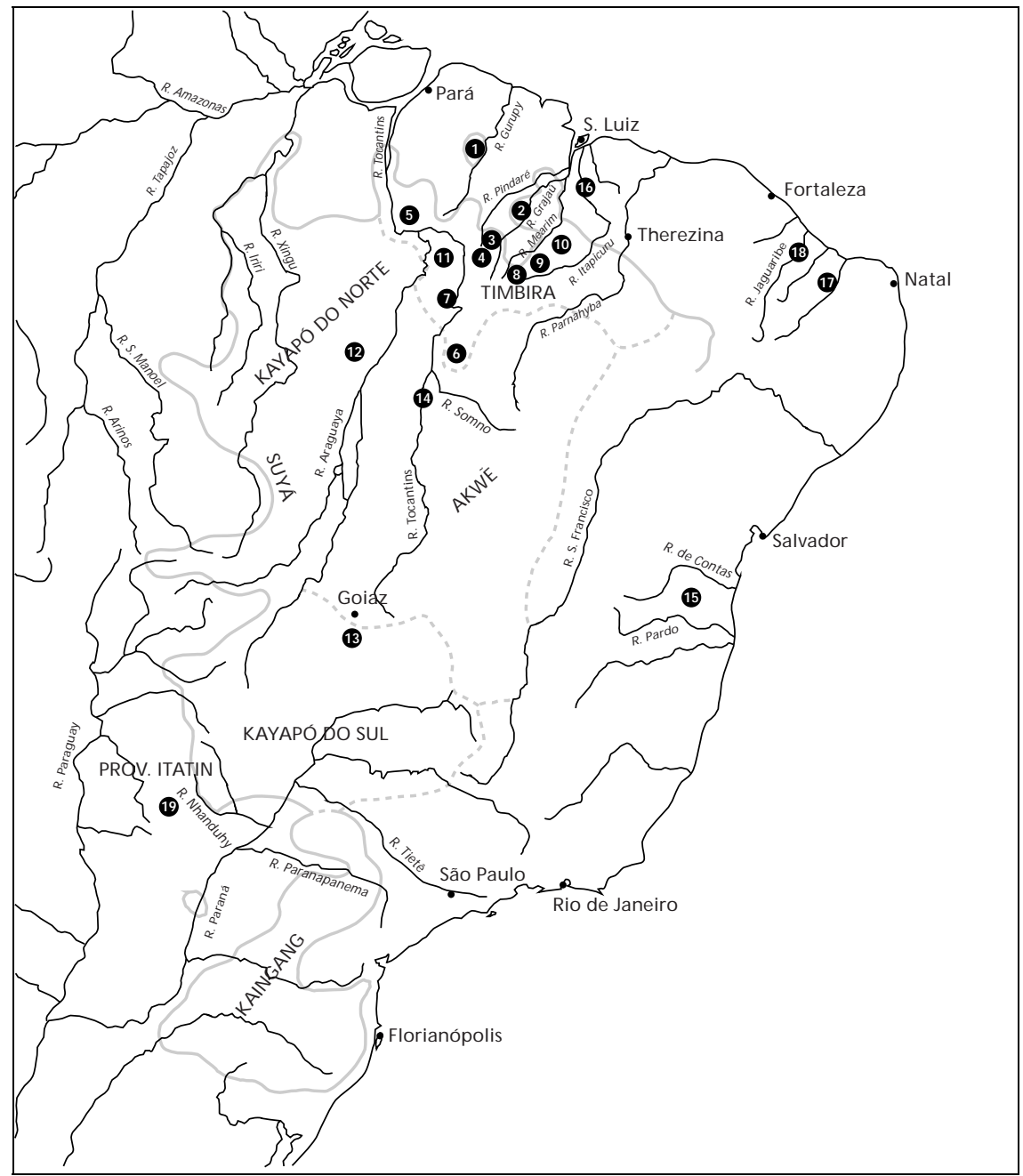

Limites da distribuição dos Jê

1 Timbira de Araparytiua

2 Kre/púmkateye

3 Pukóbye

4 Krĩkateye

5 Gaviões
6 Krahó

7 Põrekamekra

8 Apányekra

9 Ramkókamekra

10 Cákamekra

11 Apinayé

12 Kayapó do norte
13 Kayapó do sul

14 Xerente e Xavante

15 Kamakan

16 Barbados

17 Otschukayana

18 Payacú

19 Provincia Itatin

* N.T. - No original, Nimuendajú acrescentou, posteriormente, a lápis duas novas referências: os Fulnió, estudados por ele mesmo em 1934, e os índios do Brejo dos Padres, estudados por Carlos Estevão em 1937. 


\section{Tabela: Distribuição da corrida de toras*}

Tribo

1 Timbira de Araparytiua

2 Kre/pumkateye

3 Pukóbye

4 Krĩkateye

5 Gaviões

6 Krahó

7 Porekamekra

8 Apanyekra

9 Ramkokamekra

10 Cákamekra

11 Apinayé

12 Kayapó do norte

13 Kayapo do sul

14 Xerente e Chavante

15 Kamakan

16 Barbados

17 Otschukayana (Yandoin)

18 Pyacú (Payacú)

19 Prov. Itatin

20 Fulnió

21 Índios do Brejo dos Padres
Autor

Nimuendajú

Snethlage: 183

Nimuendajú

Nimuendajú

Nimuendajú

-

Snethlage: 183

Nimuendajú

Pohl, II: 205

Nimuendajú

Pompeu Sbr: 12

Snethlage: 183

Fróes Abreu: 187

Pompeu Sbr.: 12

Nimuendajú

Nimuendajú

Snethlage: 183

Oliveira: 65

Nimuendajú

Kissenberth: 55

S. Souza: 494

Pohl, I: 400

Spix \& M.: II; 574

Tuggia: 120

Vianna: 40

Nimuendajú

Wied, II: 202

Spix\& M.: 695

Martius, I; 344

Douville: 275

Moraes: 359

Rabbi: 280

Baro: 220

Barlaeus: 250

Carrilho: 136

Carrilho: 136

Techo: IV, 214

Nimuendajú

Carlos Estevão
Pesquisado/ observado; data

Psq.; 1913

Psq.; 1924

Psq.; 1929

Psq.; 1929

Psq.; 1928

Psq.; 1931

Psq.; 1925

Obs.; 1930

Psq.; 1819

Psq.; 1929

Psq.; 1929

Obs.; 1924

Psq.; 1928

Psq.; 1929

Obs.; 1929-33

Psq.; 1929

Obs.; 1926

Psq.; 1926

Obs.; 1928-32

Obs.?; 1909

Psq.?; 1812

Psq.?; 1819

Psq.; 1820

Obs.; 1852

Psq.; 1902?

Obs.; 1930

Psq.; 1817

Psq.; 1820

Psq.; 1820

Obs.?; 1833

Obs.?; 1627?

Obs.; 1633?

Obs.; 1647

Psq.; 1647

Psq.?; 1699

Psq.?; 1699

Psq.; 1680

Psq.; 1934

Psq.; 1937
Caráter

jogo de Competição

prova de casamento

competição

competição

competição

?

prova de casamento

competição

"dança com toras"

competição

prova de casamento

prova de casamento

prova de força

prova de casamento

competição

competição

prova de casamento

prova de força

competição

"dança com toras"

prova de força

"dança das toras" na

festa dos mortos

prova de casamento

competição

prova de casamento

competição

prova de força

competição entre os

candidatos a uma moça

"ginástica"

prova de casamento

competição

competição

competição

competição

competição:mulher

como prêmio

competição:mulher

como prêmio

prova de força

prova de casamento

exercício de força

* Os dois últimos números foram acrescentados a lápis posteriormente, e por isso não constam no mapa. 
Os parentes lingüística e culturalmente mais próximos dos Timbira, e principalmente dos A pinayé, são os Kayapó (do norte). Segundo indicação de Kissenberth (1912:55), "a dança com a pesada tora no ombro" representa neles o auge da festa Akre, que esse autor gostaria de associar ao culto lunar e cuja descrição lamentavelmente até hoje não publicou. Até Kissenberth, portanto, fala de uma "dança" com tora.

Os Kayapó do sul, que formavam uma tribo, ainda que aparentada, nitidamente diferente da anterior, já em 1907 estavam reduzidos à quarenta cabeças, e estão hoje provavelmente extintos por completo. Deles relata Silva e Souza (1879:494), do ano 1812: “ [...] nas vizinhanças da Paschoa (início da estação de seca) pintam em si com tinta de jenipapo botinas, peitos de armas, e fazem então com grande vozearia as suas festas e jogos, sendo o mais célebre o que chamam touro [touro, equivocadamente por tóro = tora], em que se disputam uns com os outros um grande tronco que empregam neste ministério". Portanto, uma autêntica, esportiva, corrida de toras, que se distinguia da dos Timbira apenas pelo fato de aparentemente se usar nela apenas uma tora.

Em sentido contrário vão as indicações de Pohl (1832:400) sobre a mesma tribo: a tora (uma) tinha $1^{1 / 2}$ côvados de comprimento e 12 polegadas de espessura, portanto, significativamente mais fina que a dos Timbira, e pesava $50 \mathrm{~kg}$. Nas danças noturnas, alguns andavam aos pulos com ela dentro do círculo e a lançavam então para um outro. As demais indicações de Pohl sobre a utilização da tora na festa "Gebrar Cabessa" (quebra-cabeça) que se realiza "na quaresma" e no luto por um morto, são pouco claras e, assim como sua descrição da dança noturna com tora, dificilmente derivam das suas próprias observações.

Pohl é, portanto, o primeiro que não se refere à corrida de toras entre os Kayapó e Timbira, mas sim a uma dança com tora. Dado que não a presenciou em nenhuma das duas tribos, não sei até que ponto o termo "dança" pode derivar de descrições erradas dos seus informantes ou de um equívoco dele próprio. É diferente do que ocorre com Kissenberth que, provavelmente, viu as coisas ele mesmo. O modo como um pesquisador pode deixar-se influenciar neste assunto pela maneira de se exprimir dos seus antecessores, é demonstrado por Snethlage (1930: 182), que descreve uma "dança com tora" dos Ramkókamekra que, segundo seu próprio relato, era inconfundivelmente uma corrida! Portanto, enquanto não houver descrições precisas de testemunhas oculares confiáveis, a existência de uma "dança" com tora me parece de todo duvidosa*. 
Nos Xerénte-Akwẽ vi espalhadas numerosas toras de corrida usadas, que se pareciam muito com as dos Timbira. Além disso, assisti nessa tribo a uma corrida de toras que foi realizada por duas equipes com imensas toras de $3 \mathrm{~m}$ cada uma, sempre carregadas por dois corredores simultaneamente. Um terço da tora era cilíndrico, dois terços afinavam tomando a forma cônica. A parte cilíndrica de cada tora era especialmente enfeitada com pintura e flocos de algodão colados. Tanto quanto pude entender, as equipes eram compostas, como nos Apinayé, de homens das duas moieties exogâmicas, sem consideração das também existentes classes de idade. A equipe formada pela moiety Sdakrã (do norte) levava o nome Siteromkwá, a formada pela moiety Xiptató (do sul) chamava-se Hetímhã; estes dois nomes valem apenas para a corrida de toras. As toras (kwiudé) eram carregadas em um anel de suporte (kuzdabdá) que protege os ombros. Na praça da aldeia, foram postas uma ao lado da outra: a tora dos Siteromkwá voltada para o norte; a dos Hetímhã para o sul; os lados pintados de ambas eram voltados para o leste. Em seguida, dois homens se colocaram no espaço intermediário e sopraram, com os semblantes voltados um para o outro, as pequenas flautas duplas (zedupú). Finalmente, os corredores formaram um círculo em volta das toras, seguraram-se as mãos e dançaram, cantando ao redor delas, soprando, cada vez que paravam, os trompetes de cabaça (kupawã) que alguns deles carregavam debaixo do braço. Portanto, também nessa tribo a corrida de toras é um assunto esportivo, e corridas como a que acaba de ser descrita servem para dar maior pompa a uma cerimônia social importante. No caso presente, tratava-se da concessão de um "grande" nome (“Sliemtóí) a este autor; essa cerimônia se realizou no lado leste das toras de corrida postas em pé. O velho que me admitiu na moiety Xiptató estava postado entre elas. [Foto 24]

Na literatura, a corrida de toras dos Akwẽ é mencionada por Spix e Martius (1828:574), frei Rafael Tuggia (1856:124) e Urbino Vianna (p.40); apenas frei Rafael, porém, que durante 47 anos foi missionário entre os Xerénte e Krahó, a conhecia por experiência própria. Ele menciona as festas e os jogos dos Cherente e Chavante de Theresa Christina (hoje Piabanha), "entre os quaes é o mais celebre o da Zora [erro de impressão para tora] de Buriti em cujo divertimento disputam as forças correndo e

* N.T. - Nesta passagem, anotação a lápis do autor remetendo ao estudo dos Bororo de LéviStrauss ("C ontribution a l'Étude d'Organisation Sociale des Indiens Bororo" , J ournal de la Société des Américanistes, 28:269-304, 1936). 
nesse andar ligeiro tomando uns do hombro dos outros a mesma Zora". Portanto, uma competição realizada como divertimento, e não como prova de casamento. Vianna tomou o erro de impressão "zora", em vez de "tora", pelo nome nativo da tora de corrida, pondo ainda um acento no "á", e declara que, "antigamente", a corrida de toras havia sido uma prova de casamento. Spix e Martius, cujo relato aqui tampouco se baseia na experiência própria, tendo sido reconstruído, pelo contrário, "conforme as indicações de um experiente barqueiro", contam dos Chavante que corriam com uma "tora pesando dois à três quintões, a qual lançam de si em plena corrida. O jovem que não o consegue não pode se casar mesmo."

Outro povo da família Jê, no seio do qual a corrida de toras se tornou conhecida, são os Kamakan do sul do Estado da Bahia, entre os rios Contas e Pardo. As informações sobre isso provêm de Wied-Neuwied (1821:222), Spix e Martius (1828:695) e Douville (1928:275). A tora dos Kamakan, embora de uma espécie de madeira diferente, era parecida à dos Timbira em tamanho e peso, e possuía cabos como as Para-kahák dos Ramkókamekra. Também os Kamakan faziam estradas de corrida retas e limpas, com comprimento, entretanto, apenas de um quarto de milha, correndo do fim da pista para a aldeia. Wied e Douville falam de "Einem Klotz" (uma só tora). Segundo as indicações do primeiro, os demais participantes procuravam fazer o carregador perder a tora durante a corrida. Segundo o relato do último, o carregador procurava - o que de antemão é absolutamente impossível com uma tora de 116-130 kg - ficar à frente dos demais participantes, sendo porém rendido por um substituto de 200 em 200 passos. Wied considera a corrida de toras dos Kamakan um jogo e uma prova de força, e diz apenas que jovens beldades recebiam com aplausos os corredores na chegada. Segundo Spix e Martius, entre os diversos candidatos a uma moça, ganhava aquele que conseguisse carregar a tora mais longe. Martius (1867:344), em um outro trecho, descreve a corrida de toras dos Kamakan como " ginástica", sem mencionar nenhuma relação com o casamento. Douville a declara francamente uma prova matrimonial: “[...] tout homme qui ne peut faire cet excercise n' est pás admis a prendre une femme". Pode-se ver claramente de que maneira a compreensão e representação da corrida de toras dos Kamakan como uma prova de casamento, desenvolveu-se entre 1817 (Wied) e 1833 (Douville). Dos pormenores dos três relatos, porém, resulta, sem dúvida, que também nessa tribo não podia estar em jogo uma prova das aptidões de um indivíduo, mas sim de uma equipe inteira. Se tivessem pretendido comprovar a aptidão do candidato ao casamento, certamente, o teriam 
deixado correr sozinho com a tora, e o revezamento entre tantos homens de 200 em 200 passos que o próprio Douville descreve apenas dificultaria uma avaliação das aptidões*.

A nordeste dos Timbira, entre os rios Itapicurú e Monim, no hoje Estado do Maranhão, habitava uma tribo chamada pelos portugueses de "Barbados", com base em boato falso de que se tratava de índios barbudos. É possível que os Barbados tenham estado em contato direto com os Timbira. Em todo caso, diversos elementos de sua cultura, como dardos [flechas de arremesso?], choupanas com sobrado (Snethlage 1930:155 traduz o vocábulo "sobrado" erradamente como "cama de varas"), a ausência de arco-e-flecha e a lenda da origem a partir de um formigueiro falam contra a sua ligação com o povo timbira. De sua língua nada foi conservado. Depois de muita luta, fizeram a paz em 1626-27 e foram estabelecidos em São Lourenço e São Francisco Xavier do Peritoró (São Pedro) no baixo rio Itapicurú, mais ou menos a $4^{0}$ de latitude sul. Segundo uma indicação de Moreira Pinto (1896) (“Barbados”), esses povoamentos subsistiram até 1888 , ano em que foram exterminados por uma grande enchente. Dentre as parcas informações que Simão Estação da Silveira, P. José de Moraes e Candido Mendes de Almeida fornecem sobre a tribo hoje inteiramente desaparecida, encontra-se uma referência à corrida de toras (Moraes 1860:389). Lemos aí sobre "exercícios de trabalhos e experiência de forças, como de carregar aos hombros de uma a outra parte pesadíssimos troncos de palmeiras, e na mesma velocidade da carreira passaram-nos aos dos companheiros, com tal destreza, que embora offendam aos ouvidos com o desentoado dos gritos, não deixam de agradar aos olhos com este seu jogo de barra, pela ligeireza aonde melhor experimentam as suas valentias". Isto soa como tirado do relato de uma testemunha ocular, talvez dos primeiros missionários dessa tribo, os padres jesuítas Gabriel Malagrida e João Tavares. Não se encontra nenhuma menção a qualquer relação com o casamento.

Uma das descrições mais objetivas da corrida de toras é, a meu ver, a de Jacob Rabbi (1643:280), provavelmente por volta de 1634. Ela se refere à tribo dos Otschukayana ou Tarairyou, chamados Jandoins pelos portugueses, que habitava na área do rio Assu, no atual Estado do Rio Grande do Norte, extinta desde o século XVIII. Que essa tribo não pertencia aos Jê, como Ehrenreich (1894) acreditava, R. Schüller (1912) já

\footnotetext{
* N.T. - Nota a lápis do autor: " Para os Jê do sul, o grupo Kaingang, falta a corrida de toras. O esporte nacional deles é o lançamento de bordunas".
} 
comprovou; contudo, parece-me pouco crível que tenha sido uma tribo Kirirí.

A corrida dos Otschukayana realizou-se quando mudaram de acampamento, indo do antigo para o novo. As duas toras de corrida foram deitadas no chão a uma pedrada da choupana do cacique, a uma distância de um passo duplo uma da outra. Os corredores apresentaram-se em duas equipes opostas ("in duas turmas divisus") e cada uma escolhia o mais forte entre seus membros, na nuca do qual colocavam a tora; este se punha então a correr com ela. Os outros da equipe se revezavam com ele ao longo do caminho. Os vencedores xingavam os vencidos apupandoos. Um rascunho tosco, pouco fiel ao texto, serve como ilustração.

Em 1647, Roulox Baro empreendeu sua viagem aos Otschukayana. Ele os encontrou, ao que parece, além da nascente do rio Potengy, e seguiu com eles para o litoral. Nos quase três meses em que passou em companhia deles, várias vezes assistiu a corridas de toras: "On courut l'arbre" é amiúde uma observação no seu diário. Um período de corridas de várias semanas representava o prelúdio à grande festa na qual eram perfuradas as orelhas dos meninos e o lábio inferior e bochechas dos jovens em idade de casar. Não compreendo perfeitamente se a solenidade final envolvia o casamento em massa desses mesmos jovens. Em todo caso, até uma testemunha ocular não sabe dizer se a corrida de toras era uma prova matrimonial: o cacique Jandhuy, com mais de 100 anos de idade, participou igualmente dela. As duas toras de corrida eram extremamente compridas (Baro, p. 220), com 22 pés, e consistiam em troncos descascados e alisados. Baro (p. 224) também descreve uma corrida que teve o antigo local de acampamento como ponto de partida e o novo como chegada. A primeira corrida inaugurando o período de festas tinha uma forma digna de nota: mandava-se soltar uma quantidade de ratos (Cavia perea?), anteriormente capturados para esse fim, que eram perseguidos pelos corredores e abatidos. De que maneira isso acontecia não é dito. Snethlage (1930:153) presume que fossem golpeados com as toras, o que, tratando-se de troncos de $6 \mathrm{~m}$ não é muito provável; talvez tenham sido mortos a pontapé.

Nas informações de Barlaeus, que não se baseiam em observações próprias, parece não se poder depositar muita confiança. Ele conta, por exemplo (Barlaeus 1659:695), dos Otschukayana, como estes " todos juntos com mulher/criança/servo/carreta/e carro nos quais levam os seus utensílios" vão para dentro de suas choupanas! Ploetz e Metraux (1929:279) interpretaram um trecho desse historiador (Barlaeus 1647:253), no sentido de que os vencedores na corrida de toras se tornariam chefes 
na guerra. "Victorem cohortes sequuntur", porém, talvez queira dizer apenas que as equipes de corrida corriam atrás do vencedor. Na edição alemã (Barlaeus 1659:695), o trecho diz: "Quem ora se põe na frente/ a este seguem as duas cambadas/pondo-se portanto juntos a caminho". De todo modo, não pode haver dúvidas de que a corrida de toras dos Otschukayana, tanto quanto a dos Timbira e dos Xerente, era uma competição entre duas equipes.

Enquanto nenhuma das três fontes sobre os Otschukayana registra algo sobre a relação das corridas de toras com o casamento, Carrilho (1912: 136), uns setenta anos depois, descobriu coisas semelhantes. Suas indicações, que parecem dizer respeito aos anos 1699 ou 1700, referemse aos Yandois (Otschukayana) e aos Pyacús (Payacú). Os últimos fazem parte de uma tribo hoje extinta, de língua desconhecida, que habitava nos atuais Estados do Rio G rande do Norte e Ceará, no rio Apody e, a oeste, daí até o Choro. Talvez possa ser equiparada aos Pajoke ou à tribo do cacique Pajucu, do tempo dos holandeses. Carrilho conta dessas tribos: "Exercitão-se desde mininos em destrezas, e forssas, com o lutar; correr, saltar. E levantando grandes pezos aos onbros, correm tres e coatro legoas sem descansar. E desta sorte ganhão prêmios que Entre Elles, os mayores, quem á ser nossas fermozas por molheres".

Uma anotação digna de menção, sobre corridas de toras entre habitantes da Província de Itatin, pode ser lida em Del Techo (IV, p.214), que de 1649 a 1680 foi missionário no Paraguai: "Probaban su fuerza llevando em hombros em grueso madero, y el que antes llegaba a la meta recebía honores ó premios; lo mismo cuenta Lipsio de los chilenos". Segundo ele, tratava-se de índios que "em nada se diferenciaban de los (Guarani) Del Paraná y Uruguay por lo que se refiere á idioma y costumbres”. Como "Província de Itatin", Del Techo entendeu, no entanto, toda a área entre os rios Paraná e Paraguai até o rio Butute ao norte (Botetehú, rio Miranda), cuja população, mesmo naquele tempo, não pode de modo algum ter sido constituída apenas por índios G uarani. Os Kayapó do sul estendiam-se, ainda em 1723, até o rio Nhanduny (Pires de Campos 1862:437). Ou a anotação de Del Techo refere-se a toda essa tribo, ou os G uarani do Itatin tinham adotado por empréstimo a corrida de toras daqueles seus vizinhos à nordeste. O que significa a indicação de Lipsio (?) e dos chilenos não compreendo muito bem. A té onde eu saiba, nada comparável a uma corrida de toras é conhecido entre os Guarani.

Sempre repeti para mim mesmo que talvez pudesse haver uma ligação qualquer entre a corrida de toras e o casamento, de modo que o último fosse diretamente condicionado pela primeira. Mas, por outro lado, 
tais ligações, se de todo existissem, teriam de ser tão evidentes que pudessem ter sido compreendidas por pessoas que não tinham a mínima noção da existência de moieties, classes de idades, grupos de pintura, divisão de estações do ano e sociedades de festa. A opinião de Snethlage, de que a corrida representava uma prova de casamento, não se fundamenta em um caso vivenciado, mas na "confirmação" de tal concepção por um "prestigiado" da aldeia do Ponto* que lá estava disposto a renunciar à "prova”, porque queriam casá-lo (Snethlage 1930:183, 173). Nas duas coisas acredito cegamente; no entanto, a prova não é exigida por ninguém, e o que há precisamente com a confirmação deste assunto já foi dito no início. O fato de que nem um só informante, para a corrida de toras como prova de casamento, fizesse a menor idéia de quem eram ao certo os corredores, devia ser suficiente por si só para demonstrar a inconsistência dessa opinião. Mesmo assim quero, antecipando-me a eventuais futuras objeções, chamar a atenção para as seguintes conexões.

A bipartição mais importante, mesmo que não absolutamente exclusiva, para a corrida de toras dos Ramkókamekra é, como vimos, aquela em $2 \times 2$ classes de idade leste e oeste. A totalidade de seus membros representa a comunidade esportiva ativa. A admissão nessa comunidade ocorre com a instalação de novas classes de idade no pátio, no início do ciclo de iniciação. Antes do início de sua iniciação ninguém pertence, portanto, oficialmente, a essa comunidade esportiva ativa. Antes do encerramento da iniciação ninguém, pois, podia se casar, ao menos antigamente (hoje não se leva mais isto tão a sério). Os jovens, em virtude disso, só podiam contrair matrimônio dez anos depois de ingressar em um partido de corrida. Essa relação é, portanto, meramente temporal; uma relação referencial existe apenas entre a iniciação e o casamento. A entrada em um partido de corrida, por outro lado, é um efeito colateral da iniciação, realizando-se automaticamente, mas seu motivo, no entanto, não é criar partidos de corrida. Além disso, nas corridas de toras, não importa, como vimos, o rendimento individual, mas sim o das equipes. $\mathrm{O}$ corredor ruim, assim que tenha concluído a iniciação, poderá casar-se tanto quanto o melhor corredor, ainda que, provavelmente, muitas moças prefiram os últimos aos primeiros. Se ele, porém, for um caçador competente e, além disso, um rapaz trabalhador, então se perdoará de bom grado o seu péssimo rendimento na corrida. Para a interpretação da corrida 
de toras como uma prova de casamento direta, essa cadeia de relações entre comunidade esportiva, classe de idade, iniciação e casamento não se deixa explorar.

Nenhuma lenda dos Timbira faz qualquer alusão à origem da corrida de toras, e hoje, evidentemente, nenhum índio vai, tampouco, quebrar a cabeça com isso. Por mim, também só posso exprimir suposições bastante vagas que, no entanto, quero acrescentar aqui, pois partem de costumes e concepções indígenas.

Os Timbira fazem parte dos índios que, em combate, se empenham ao máximo para não deixar cair nenhum companheiro ferido ou morto nas mãos do inimigo. Até os cadáveres dos tombados, na medida do possível, eram não apenas retirados em segurança, mas levados para casa a fim de se poder enterrá-los de acordo com o cerimonial dominante. A corrida de toras poderia ter nascido do reconhecimento da necessidade de exercitar-se para semelhantes circunstâncias. Entre os Kaingang do rio Ivahy, vi como os garotos treinavam escaladas da seguinte maneira: “C omo vocês procedem se o jaguar vier?", perguntou um, depois do que, todos, ao desafio, escalaram as árvores. "E como vocês procedem se um companheiro chamar por socorro?” Imediatamente todos tornaram a descer e saltar com a maior rapidez. Assim que um Timbira fazia a pergunta análoga: "Como vocês procedem se seu companheiro tomba em combate?", era inventada a corrida de toras. Talvez o costume, acima mencionado, de caracterizar torinhas Para-re como seres humanos, seja uma recordação daquele tempo primordial, quando ainda se sabia que as toras de corrida representavam, sobretudo, homens.

Gotemburgo, 31 de julho de 1934

Tradução: Hans Peter Welper e Elena Welper

Revisão Técnica: Marcela Coelho de Souza 


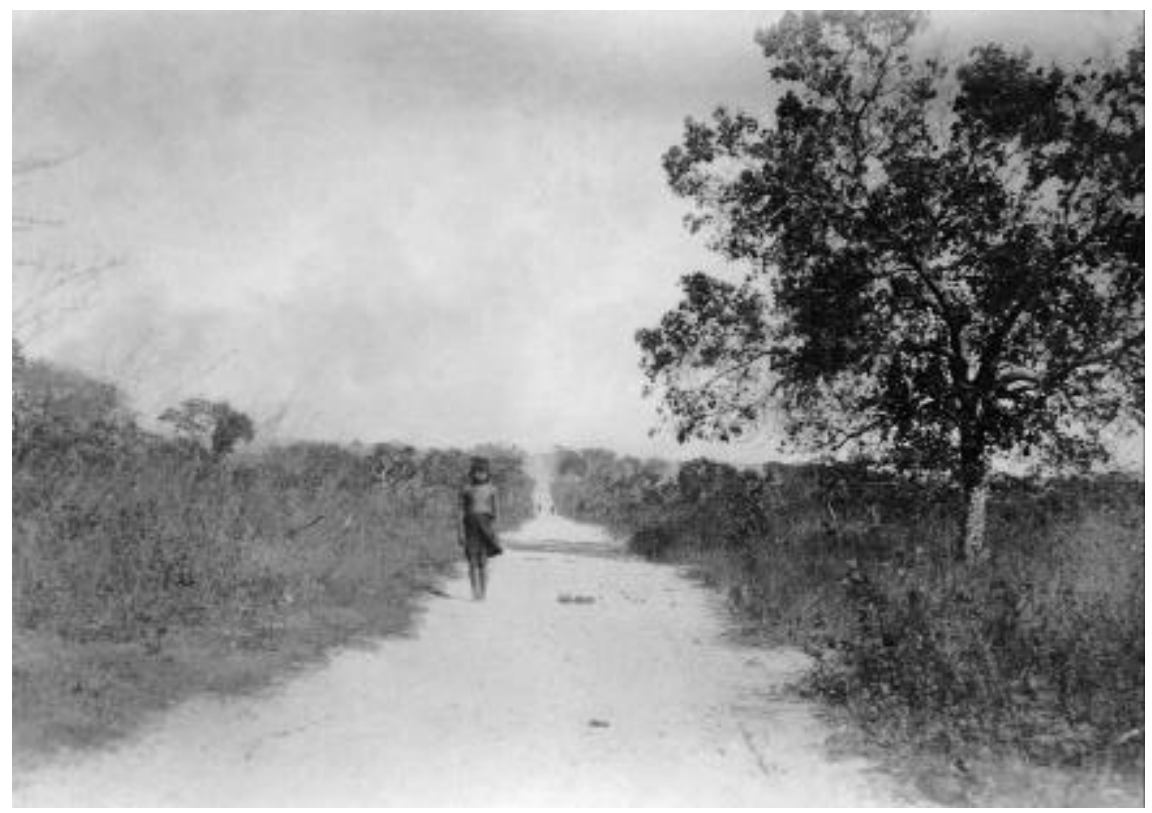

1

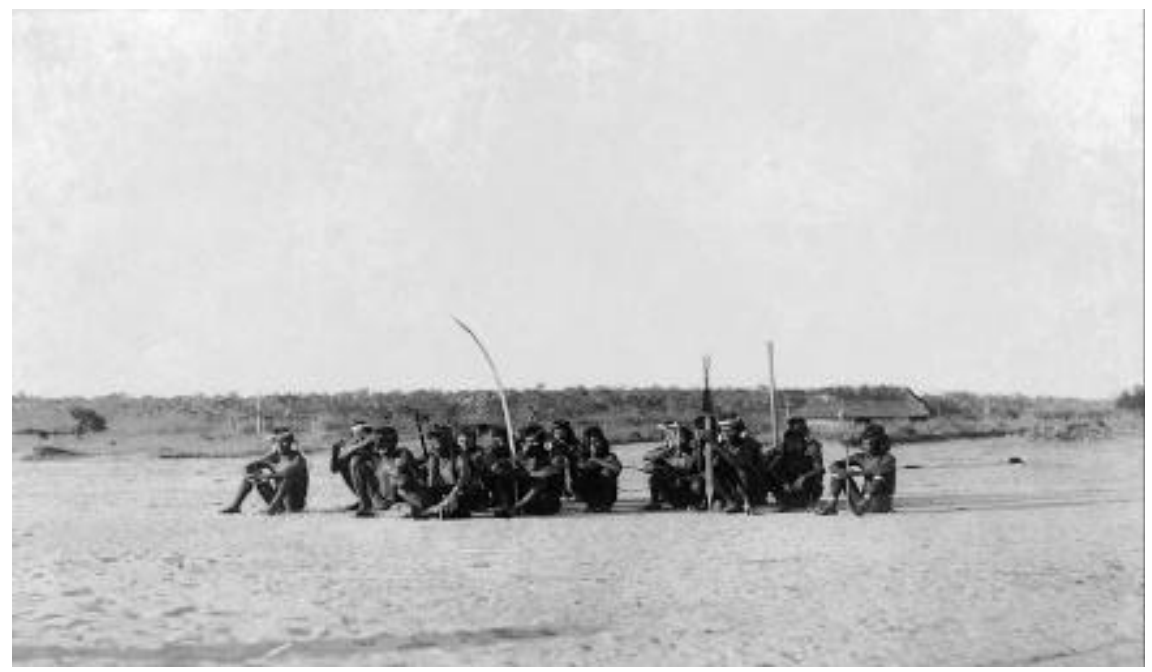

2

1

Ramkókamekra: estrada de corrida do oeste

2

Ramkókamekra: a classe de idade Kapranpotikama (incompleta) no pátio 


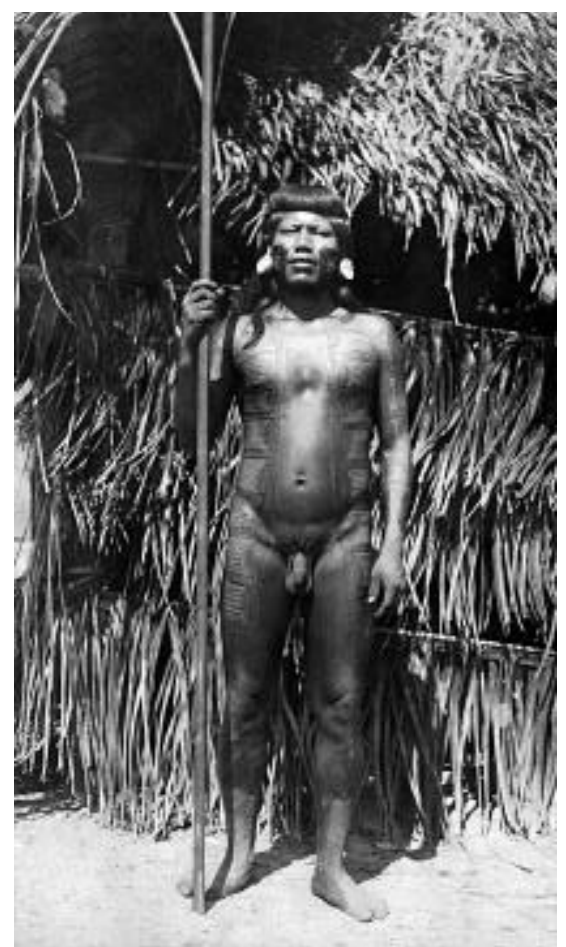

3

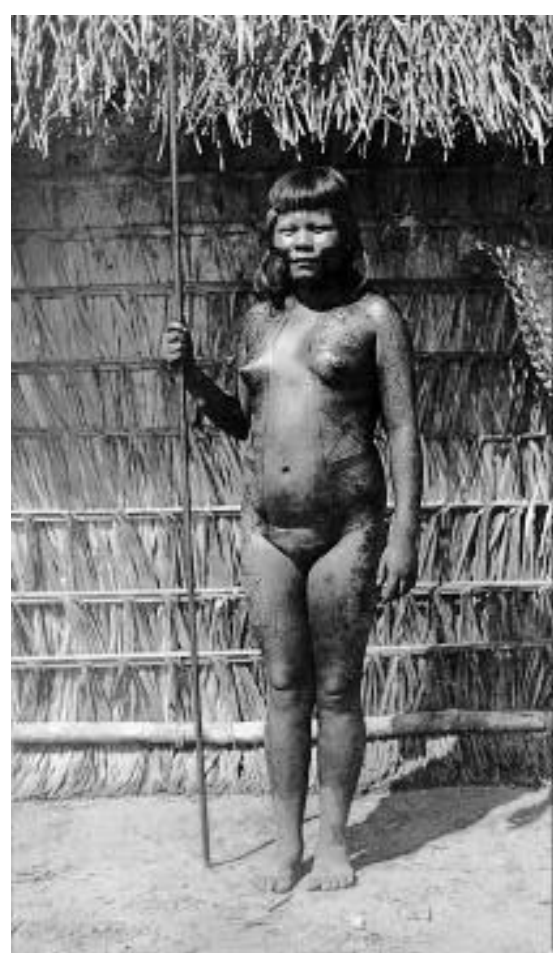

4

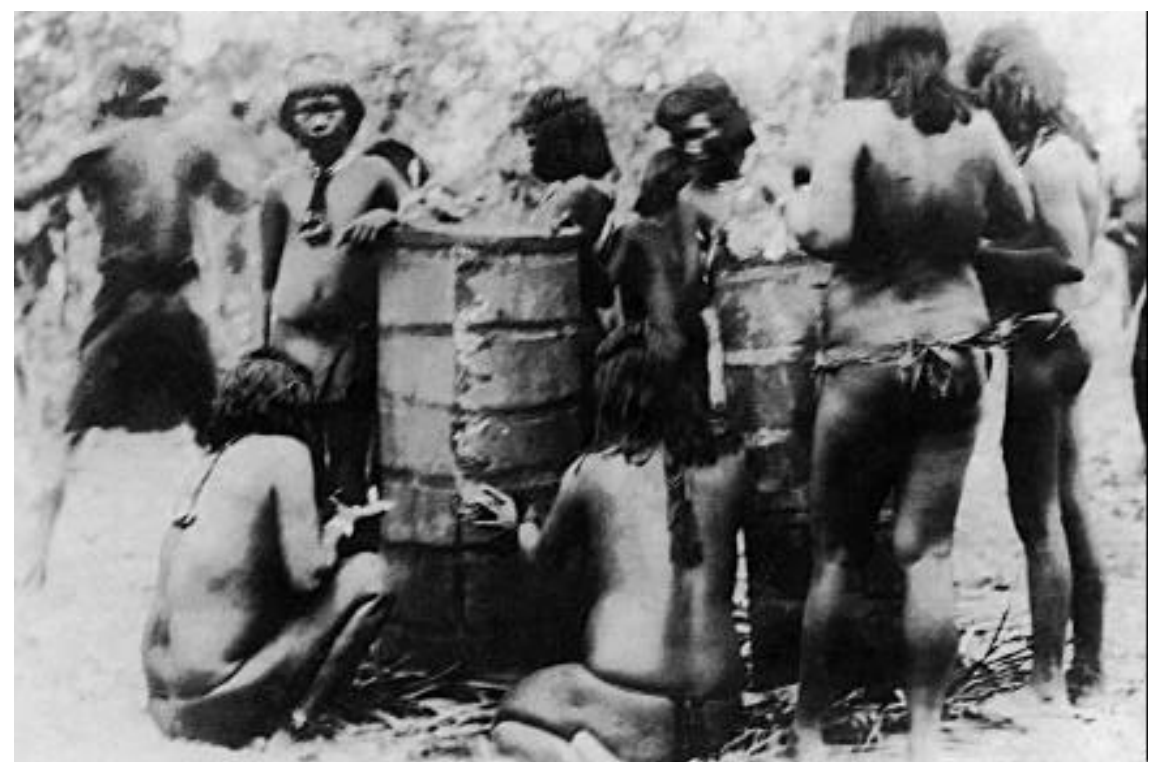




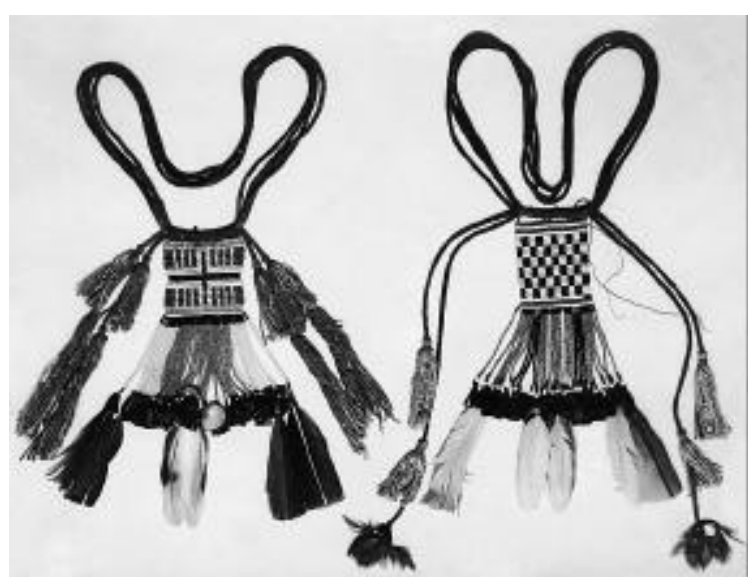

6

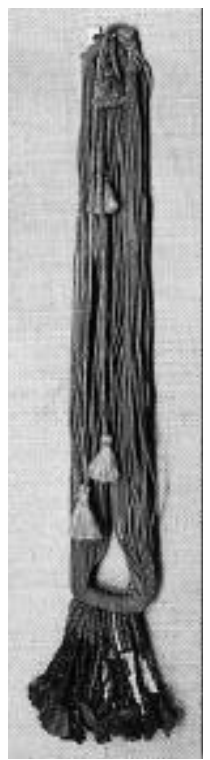

8

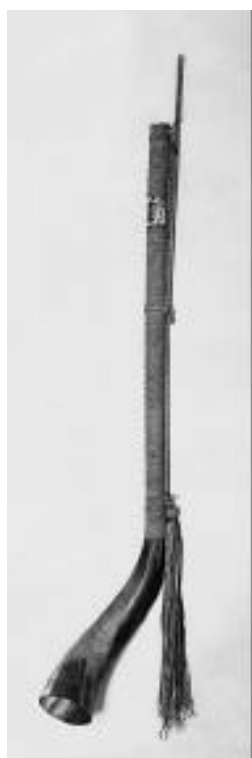

9

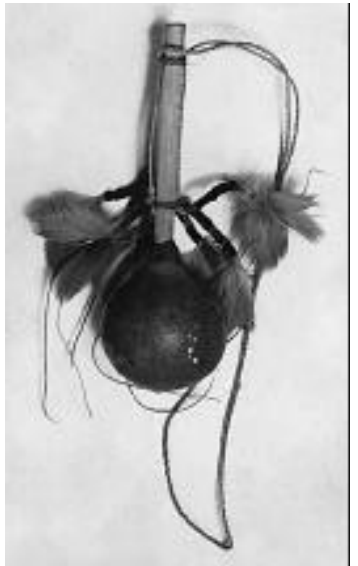

7
Kara/hí, líder de classe da moiety oeste da classe Põhitíkama. Pintura do grupo Codn (Ramkókamekra)

4

Koté, Mekuicwé da moiety leste da classe Põhitíkama. Pintura do grupo Cépre (Ramkókamekra)

5

Apinayé: mulheres pintando as toras Para-kapé

6

Apinayé: cinto de corrida com bordado de miçangas e pendentes de matraca

7

Me-õ-i-ratag-re

Ramkókamekra: cinto de corrida com pendentes de matraca

9

Ramkókamekra: trompete

10

Ramkókamekra: faixa de barbantes com ocarinas 


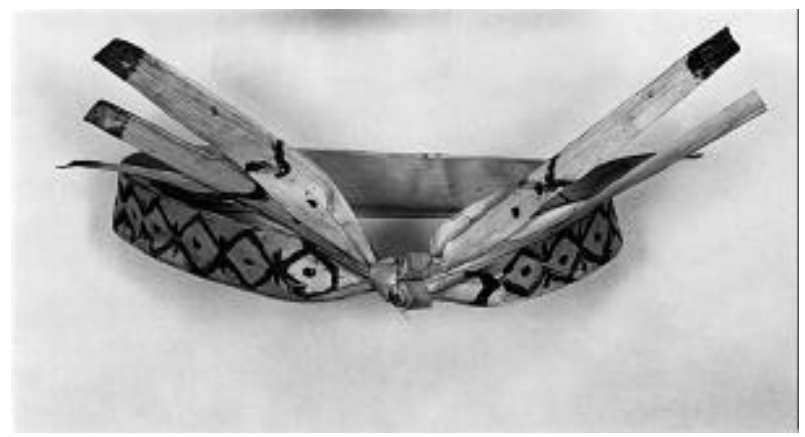

11

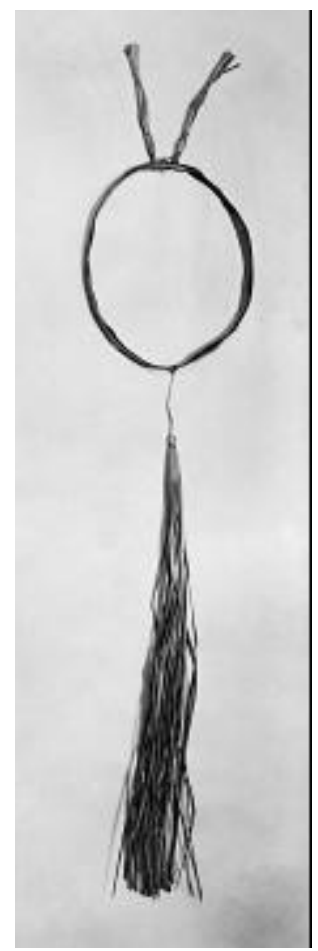

12

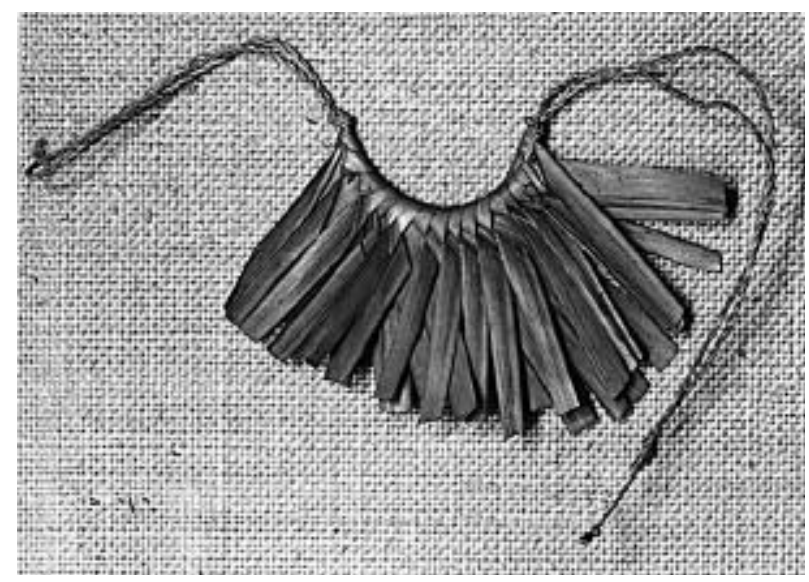

13

11

Apinayé: testeira de palha de babaçu. As pontas pintadas de preto indicam que seu portador pertence à equipe de corredores Katám da moiety oeste

12

Ramkókamekra: testeira com cauda de palha

13

Ramkókamekra: leque de palha para amarrar o cabelo da nuca 


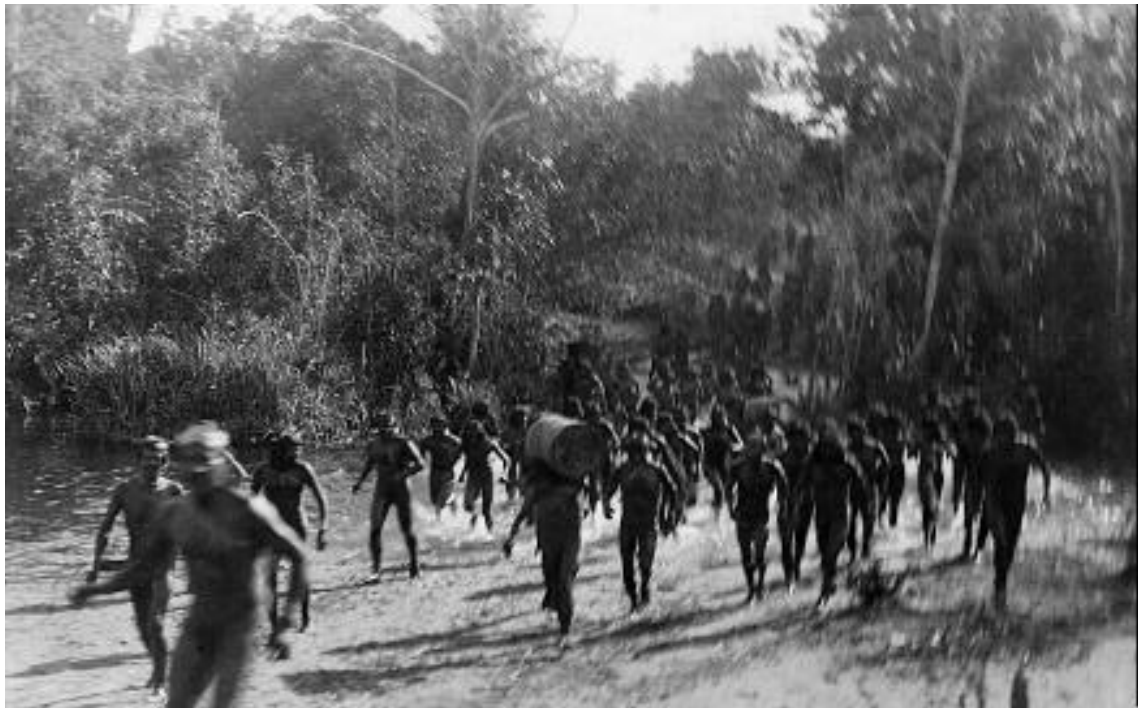

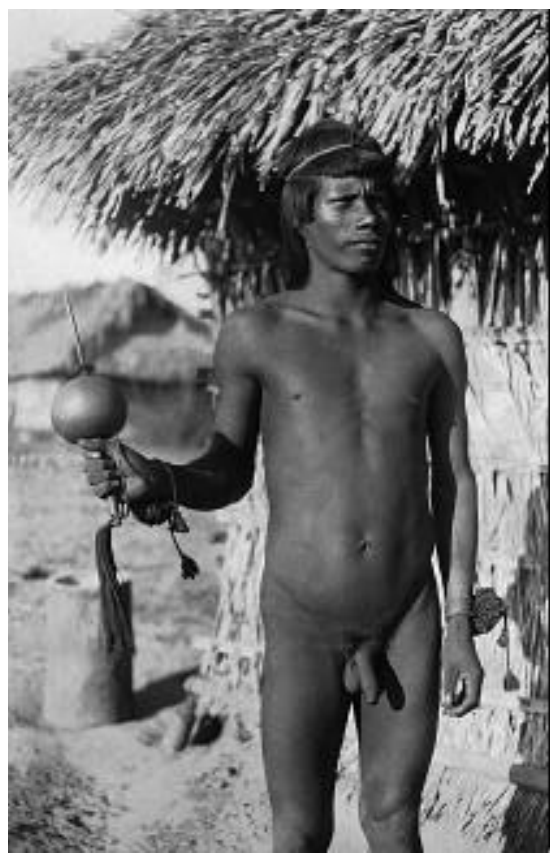

15
14

Ramkókamekra: corrida de toras na passagem de um riacho

15

Ramkókamekra: Tep-yet, o melhor corredor da classe Põhitíkama. Como ele é, também, o melhor cantor de sua classe, leva o chocalho de dança e veste pulseiras de algodão 


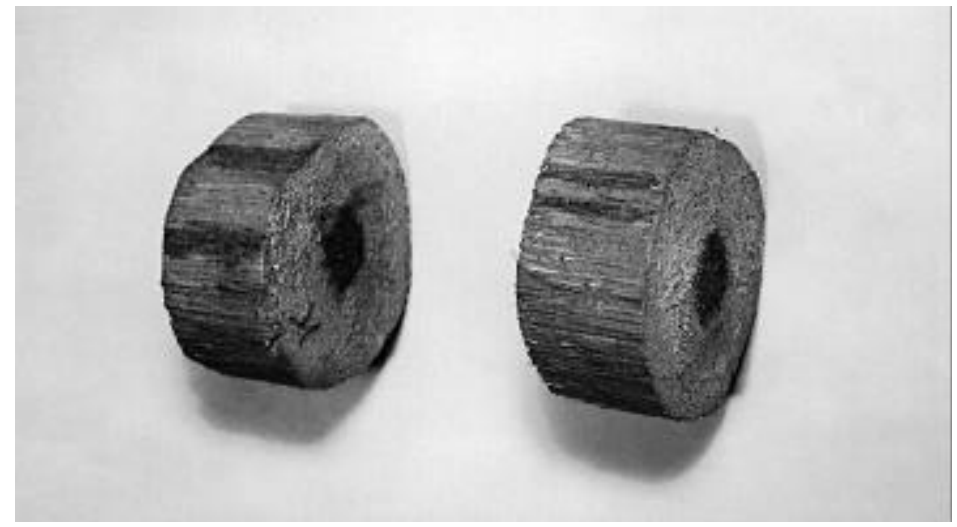

16

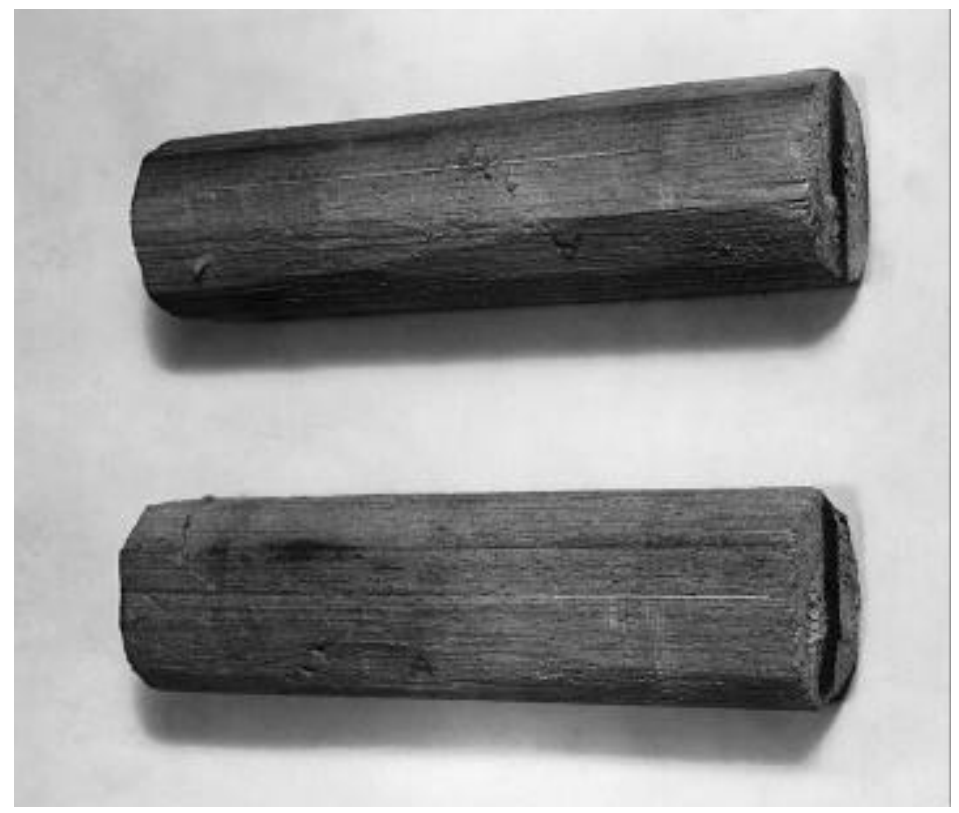



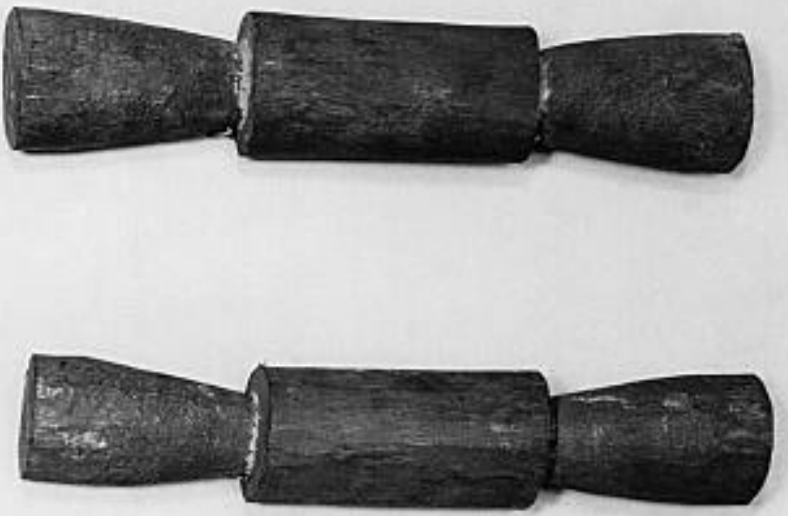

16

Ramkókamekra: o primeiro par de torinhas de corrida dos Kámakra.

17

Ramkókamekra: o primeiro par de torinhas de corrrida dos Atúkamakra.

\section{8}

Para-re, as torinhas de corrida das almas dos mortos.

19

Ramkókamekra: enfeite de nuca dos líderes de classe que estão concluindo as cerimônias de iniciação do Ketuayé e Pepyé na corrida Para-re

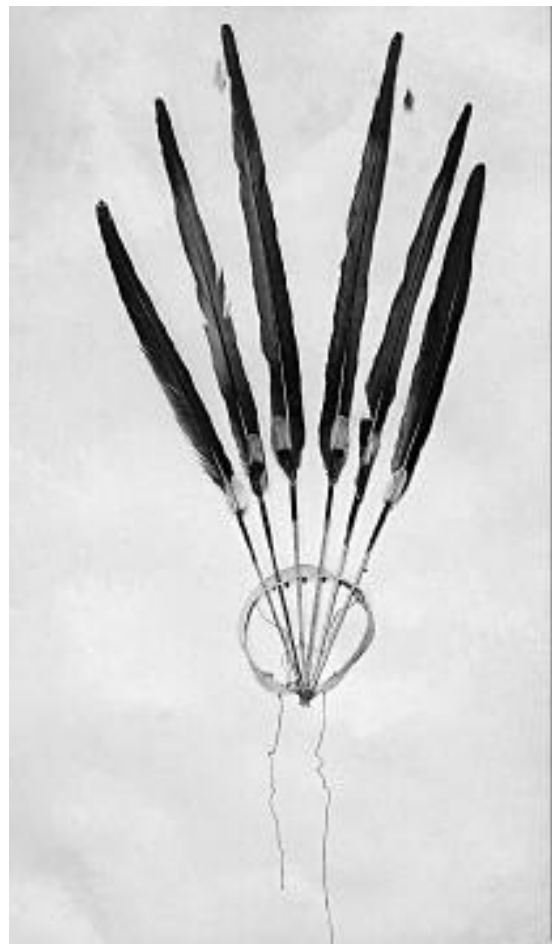



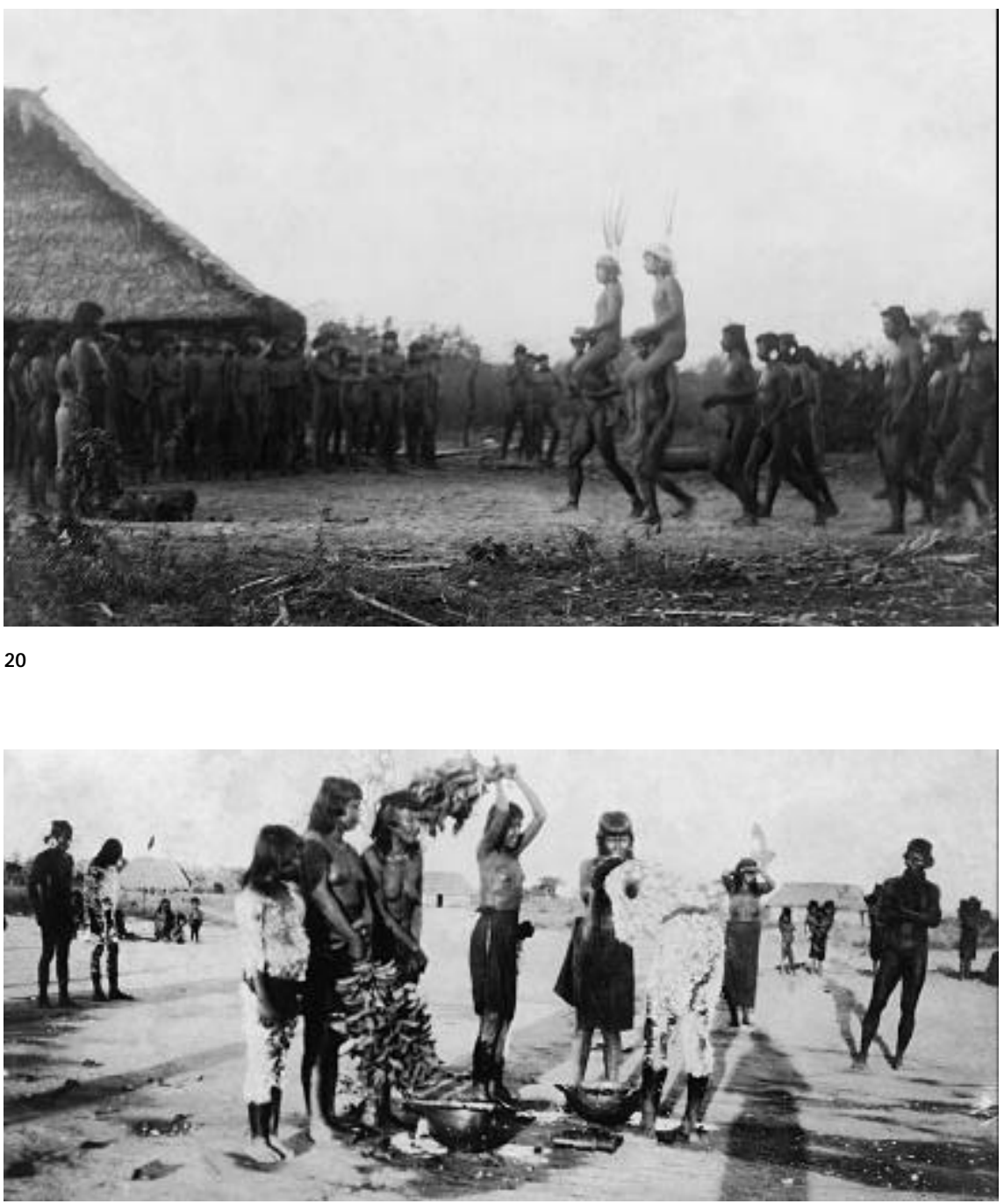

21 
20

Ramkókamekra: os dois líderes das classes que estão concluindo o Pepyé, na chegada da corrida Para-re

21

Ramkókamekra: lavagem e açoitamento dos corredores Para-re no Ketuayé. Em frente às cabaças de água do lado direito, estão as duas Para-re

\section{2}

Ramkókamekra: a faixa peitoral feita de trançado de buriti. Na do meio, um pendente de bico de tucano e pequenas toras Para-re

\section{3} cercada por toras de corrida velhas
Ramkókamekra: cova de criança

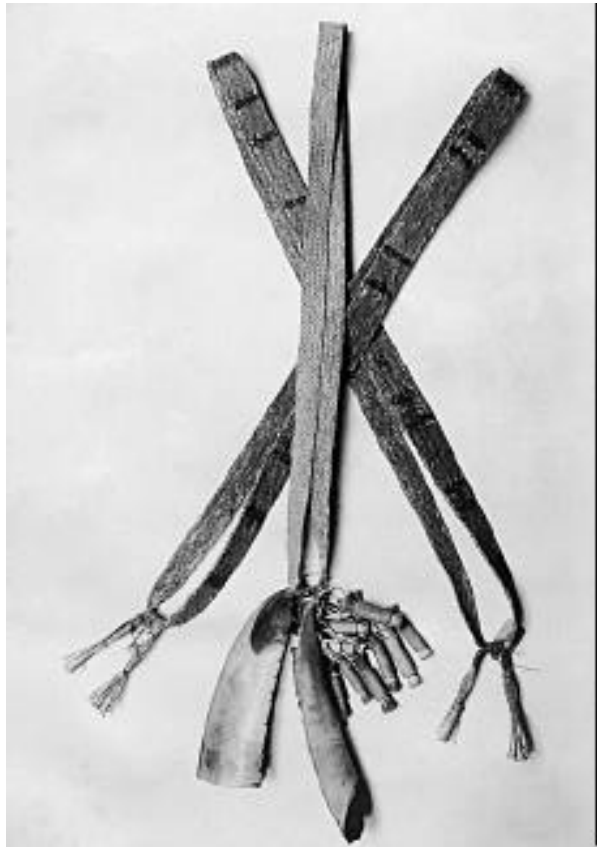

22

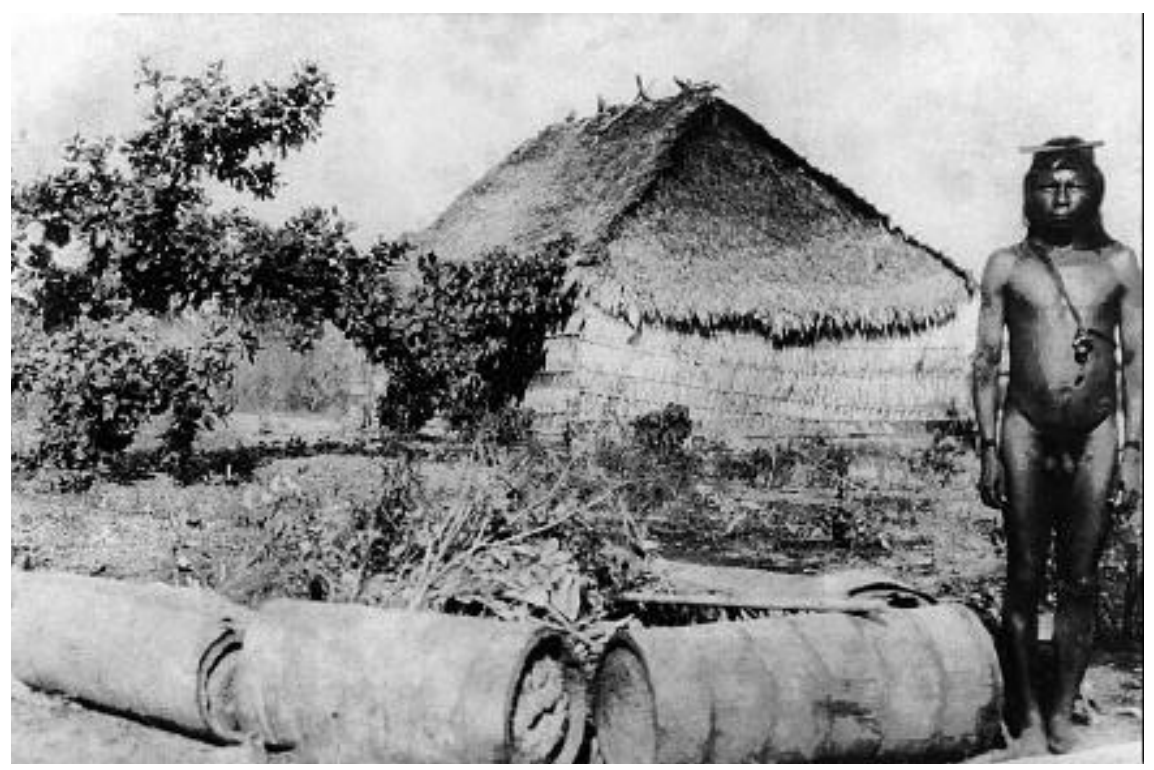




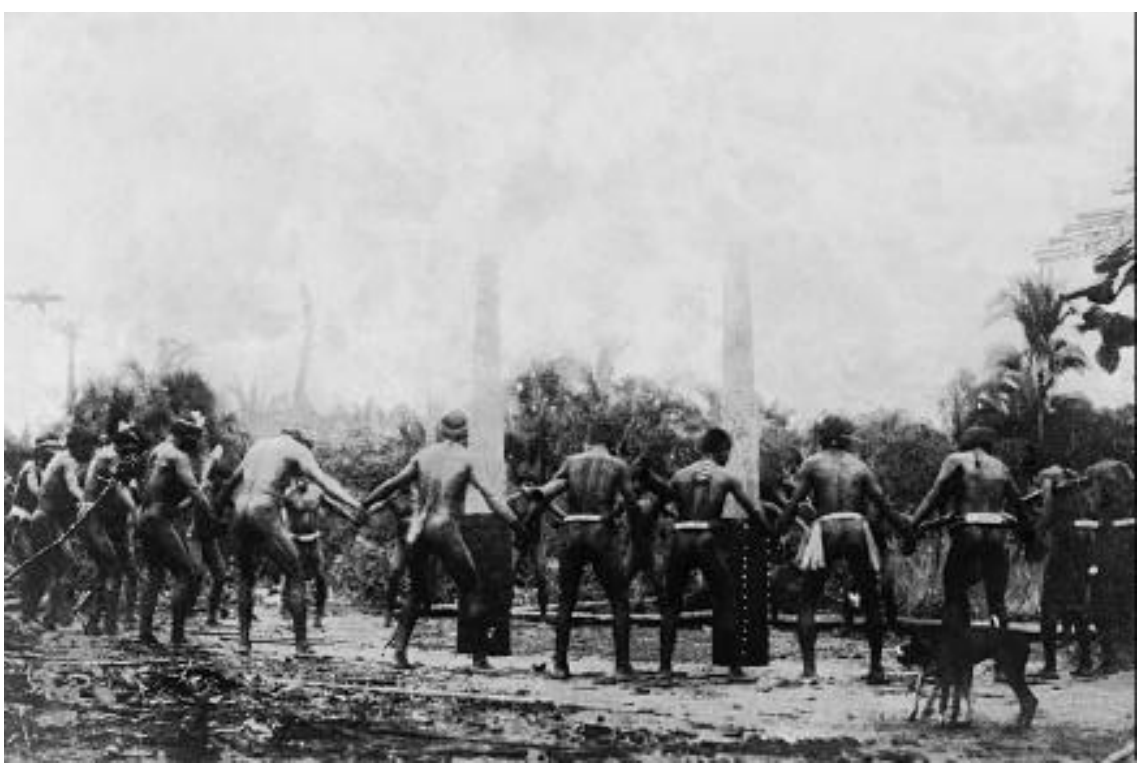

24 


\section{Referências bibliográficas*}

Almeida (C andido Mendes de): "Notas para a História Pátria” . 4. Art. Rev. Inst. Hist. Geogr. XLI. 2a Rio. 1878.

Barlaeus (Casper): a) Rerum der Octennium in Brasilia et alibi nuper gestarum, sub praefectura comitis J. Mauritii Nassoviae etc... Amstelodami. MDCXLVII.

b) Brasilianische Geschichte. Bey Achtjahriger in selbigen Landen gefuhrter Regierung Seiner Furstlichen Gnaden Herrn Johann Moritz Fursten von Nassau etc. Esrtlich in Latein durch Gasparum Barlaeum beschrieben. Vnd jetzo in Teutsche Sprache ubersetzt. Cleve. 1659.

Baro (Roulox): “Relation du Voyage de... Interprete et Ambassadeur ordinaire de la Compagnie des Indes d'Occident, de la part des dans la terra ferme du Brasil. Comemencé le troisiesme Avril 1647. Et finy le quatorziesme Iuillet de la mesme anné”. Traduit d'Hollandois en François par pierre Moreau de Paray en Charolois. - Relation veritables et curieuses de liste de Madagascar, et du Bresil. Paris. MDCLI.

Carrilho (Pedro): Memoria sobre os Ïndios do Brasil. Rev. Inst. Hist. Geogr. do Rio Grande do Norte. VII. Natal. 1912.

Douville (J. B.): Voyage chez les sauvages du Bresil fait pendant les années 1833, 1834 e 1835. Publicado por A. Metraux in Rev. Inst. de Etn.

I. Tucuman. 1928.

Ehrenreich (Paul): "Über einige Bildnisse südamerikanischer Indianer”. Globus LXVI. Braunschweig 1894.

Fróes Abreu (S.): Na Terra das Palmeiras. Rio de Janeiro, 1931.
Kissenberth (Wilhelm): "Über die hauptsächlichsten Ergebnisse der Araguaya-Reise”. Zeitschr. F. Ethn. XLIV. Berlin, 1912.

Martius (Karl Friedrich Phil. Von): Beiträge zur Ethnographie und Sprachenkunde Amerikas. I: Zur Ethnographie. Leipzig, 1867.

Moraes (P. José de): História da Companhia de J esus na extincta Provincia do $M$ aranhão e Pará - M émorias para a História do extincto Estado do Maranhão. Colligidas e anotadas por Candido Mendes de Almeida. Tomo I, Rio, 1860.

Moreira Pinto (Alfredo): Apontamentos para o Diccionário G eográphico do Brazil. Rio. 1896.

Nimuendajú (Curt): Im Gebiet der GêVölker. A nthropos, XXIV. MödlingWien.

Oliveira (Carlos Estevão de): Os Apinagé do Alto Tocantins. Boletim do M useu Nacional, VI. Rio de Janeiro. 1930

Pires de Campos (Antonio): Breve notícia que dá o Capitão... do gentio bárbaro que há na derrota da viagem das Minas de Cuyaba. Rev. Inst. Hist. Geogr., XXV. Rio. 1862.

Ploetz e Metraux: La Civilization materielle et la vie sociale et religieuse des indiens Ze du Brésil Merdidional et Oriental. Rev. del Inst. de Etn., I. Tucuman. 1929.

Pohl (Johann Emanuel): Reise im Innern von Brasilien. Wien. 1832.

Pompeu Sobrinho (TH.): Merrime. Fortaleza. 1930.

Rabbi (Jacob): in Guilielmi Pisonis et Georgi Marcgravi. Historia Naturalis Brasilae. Lugdun. Batavorum. 1643. 
Ribeiro (Francisco de Paula): "Memoria sobre as Nações Gentias que presentemente habitam o Continente do Maranhão”. Rev. Inst. Hist. Geogr., III. Rio. 1841.

Schüller (Rudolf): Zur Affinität der Tapuya-Indianer. Int. A rchiv f. Ethn., XXI. Leiden. 1912.

Silva e Souza (P. Luiz Antonio de): Memoria sobre o descobrimento etc. da Capitania de Goyas. Rev. Inst. Hist. Geogr., XII. Rio. 1879.

Snethlage (E. Heinrich): Unter nordostbrasilianischen Indianern. Zeitschr. f. Ethn. Berlin. 1930.

Spix (Dr. Joh. Bapt. Von) e Martius (Dr. Carl Friedrich Phil. Von): Reise in Brasilien. München. 1828.

Tuggia (Fr. Rafael): Mappa dos Índios Cherentes e Chavantes etc. Rev. Inst. Hist. Geogr., XIX. Rio. 1856.

Vianna (Urbino): Akuen ou Xerente.

Wied-Neuwied (Prinz Maximilian von): Reise nach Brasilien in den J ahren 1815-1817. Frankfurt am Main. 1821. 